\title{
Crosstalk of CREB and Fos/Jun on a single cis-element: transcriptional repression of the steroidogenic acute regulatory protein gene
}

\author{
Pulak R Manna and Douglas M Stocco \\ Department of Cell Biology and Biochemistry, Texas Tech University Health Sciences Center, Lubbock, Texas 79430, USA \\ (Correspondence should be addressed to D M Stocco; Email: doug.stocco@ttmc.ttuhsc.edu)
}

\begin{abstract}
Transcriptional regulation of the steroidogenic acute regulatory (StAR) protein gene by cAMP-dependent mechanisms occurs in the absence of a consensus cAMP-response element (CRE; TGACGTCA) and is mediated by several sequencespecific transcription factors. We previously identified three CRE-like sites (within the $-151 /-1 \mathrm{bp}$ cAMP-responsive region of the mouse StARgene), of which the CRE2 site overlaps with an activator protein-1 (AP-1) motif (TGACTGA, designated as CRE2/AP-1) that can bind both CRE and AP-1 DNA-binding proteins. The present studies were aimed at exploring the functional crosstalk between CREB (CRE-binding protein) and cFos/cJun (AP-1 family members) on the CRE2/AP-1 element and its role in regulating transcription of the StARgene. Using MA-10 mouse Leydig tumor cells, we demonstrate that the CRE and $A P-1$ families of proteins interact with the CRE2/AP-1 sequence. CREB, $c F$ os, and cJun proteins were found to bind to the CRE2/AP-1 motif but not the CRE1 and CRE3 sites. Treatment with the CAMP analog $(\mathrm{Bu})_{2} \mathrm{CAMP}$ augmented phosphorylation of CREB $\left(\mathrm{Ser}^{133}\right)$, cFos $\left(\mathrm{Thr}^{325}\right)$, and cJun $\left(\mathrm{ser}^{73}\right)$. Chromatin immunoprecipitation studies revealed that the induction of CREB, cFos, and cJun by $(\mathrm{Bu})_{2} \mathrm{CAMP}$ was correlated with protein-DNA interactions and recruitment of the coactivator CREB-binding protein (CBP) to the StAR promoter. EMSA studies employing CREB and cFos/cJun proteins demonstrated competition between these factors for binding to the CRE2/AP-1 motif. Transfection of cells containing the $-151 /-1$ StAR reporter with CREB and cFos/cJun resulted in trans-repression of the StARgene, an event tightly associated with CBP, demonstrating that both CREB and Fos/Jun compete with each other for binding with limited amounts of intracellular CBP. Overexpression of adenovirus E1A, which binds and inactivates CBP, markedly suppressed StAR gene expression. Ectopic expression of CBP eliminated the repression of the StAR gene by E1A and potentiated the activity of CREB and cFos/cJun on StAR promoter responsiveness. These findings identify molecular events involved in crosstalk between CREB and cFos/cJun, which confer both gain and loss of function on a single cis-element in fine-tuning of the regulatory events involved in transcription of the StAR gene.
\end{abstract}

Journal of Molecular Endocrinology (2007) 39, 261-277

\section{Introduction}

The steroidogenic acute regulatory (StAR) protein regulates the rate-limiting step in steroidogenesis, the transfer of cholesterol from the outer to the inner mitochondrial membrane in steroidogenic cells (Clark et al. 1994, Waterman 1995, Stocco \& Clark 1996, Manna \& Stocco 2005). The strongest evidence for the critical role of StAR in regulating steroid biosynthesis comes from patients suffering from congenital lipoid adrenal hyperplasia, as well as studies on StAR knockout mice, in which both gonadal and adrenal steroids are markedly impaired due to mutations in the StAR gene (Caron et al. 1997a,b, Hasegawa et al. 2000). Studies have demonstrated that regulation of StAR expression occurs through cAMP-mediated mechanisms that involve transcriptional induction. Despite our current knowledge surrounding the regulation of the StAR gene, a complete understanding of the cAMP-dependent signaling events involved in this process is still lacking.

Transcriptional regulation of the StAR gene involves the concerted action of multiple proteins that bind directly or indirectly to DNA regulatory elements (Wooton-Kee \& Clark 2000, Manna et al. 2003a,b, 2004, Hiroi et al. 2004). Activation of transcription by cAMP signaling is classically mediated through the interaction of the cAMP-response element (CRE)-binding protein (CREB) with a conserved CRE (TGACGTCA), or a minor variation thereof, found in the promoter region of several cAMP-responsive genes (Montminy et al. 1986, Meyer \& Habener 1993, Montminy 1997, De Cesare \& Sassone-Corsi 2000). While the StAR gene promoter lacks a consensus CRE, several transacting factors within the $150 \mathrm{bp}$ (relative to the transcription start site) cAMP-responsive region have been demonstrated to be instrumental in StAR gene expression (Manna et al. 2003a, 2004, Clem et al. 2005). Previously, we have 
identified three CRE-like elements (including an overlapping CRE2/AP-1 motif, TGACTGA, -81/-75), and the roles of CRE (CREB/CRE modulator (CREM)) and AP-1 (Fos/Jun) family members in transcription of the StAR gene have been demonstrated (Manna et al. $2002 b, 2003 b$, 2004). However, those studies did not provide information on the molecular events by which these families of proteins associate with the CRE2/AP-1 site to regulate the transcriptional machinery involved in StAR gene expression.

The CRE/activating transcription factor (ATF) (TGACGTGA) and AP-1/phorbol 12-O-tetradecanoate 13 acetate responsive element (TRE) (TGA(C/G)TCA) sequence motifs are two of the major classes of regulatory elements that contribute transcriptional regulation through a variety of extracellular signals (Sassone-Corsi et al. 1990, Hai \& Curran 1991, Montminy 1997). The former site is recognized by proteins of the CREB and ATF families, while the latter is recognized by AP-1 family members Fos (cFos, FosB, Fra1, and Fra2/ and Jun (cJun, JunB, and JunD) (Rauscher et al. 1988, Hai \& Curran 1991). These families of proteins are structurally similar, share the basic leucine-zipper (bZIP) motif, but they have discrete transcriptional activities, interactions with several transcription factors, and other properties that contribute to their regulatory functions (Dwarki et al. 1990, Habener 1990, Hai \& Curran 1991, Sassone-Corsi 1995, Manna et al. 2004). The difference between CRE and AP-1 consensus sequences is only one nucleotide (CRE, TGACGTCA; AP1, TGACTCA) and thus, overlap and/or crosstalk affecting transcription can occur (Masquilier \& Sassone-Corsi 1992, Rutberg et al. 1999, Chen \& Guo 2000). However, the incidence of such events in the transcriptional regulation of the StAR gene has not been described.

CREB/ATF and Fos/Jun are members of the activator proteins (APs), which interact with themselves or each other to form selective dimers that bind to closely related CRE and AP-1 sequences and result in varied transcriptional responses (Dwarki et al. 1990, Hai \& Curran 1991, Millhouse et al. 1998, Rutberg et al. 1999). CREB binds to DNA as a homodimer, is activated upon phosphorylation at Ser133 by several kinases including protein kinase A, and interacts with the CREB-binding protein (CBP; Chrivia et al. 1993, Parker et al. 1996, Shaywitz \& Greenberg 1999, Richards 2001). On the other hand, Fos members bind to DNA as heterodimers with Jun proteins and with selected members of the CREB/ATF family, but do not form homodimers, whereas Jun members function as homo- or heterodimers among themselves or with members of the Fos and CREB/ATF families (Hai \& Curran 1991, Kerppola \& Curran 1991, O'Shea et al. 1992). Expression and activities of Fos and Jun are regulated by a plethora of extracellular signals and phosphorylation of Fos/Jun on Ser and Thr residues by multiple kinases have been reported to be involved in the transcription of many genes (Boyle et al. 1991, Abate et al.
1993, Manna et al. 2006b). CBP and its functional homolog, p300 (Eckner et al. 1994; referred to as CBP/ p300), are transcriptional coactivators, which harbor multiple functional domains, possess histone acetyltransferase (HAT) activity, interact with a variety of transcription factors including CREB (Kwok et al. 1994), cFos (Bannister \& Kouzarides 1995), and cJun (Arias et al. 1994, Bannister et al. 1995). CBP/p300 does not bind to DNA but rather acts as a bridge between the sequence-specific transcription factors and the general transcriptional machinery and thus promote transcriptional activation (reviewed in Ref. (Vo \& Goodman 2001)). Studies have indicated a role for CBP in StAR's transcription (Hiroi et al. 2004, Clem et al. 2005, Silverman et al. 2006); however, its relevance remains to be elucidated.

The identification of an overlapping CRE2/AP-1 element in the cAMP-responsive region of the mouse StAR gene responsive to both CREB and Fos/Jun prompted us to explore the potential assembly of such complexes and determine whether they could independently, synergistically, or negatively influence transcription of the StAR gene. The experimental approaches utilized here provide evidence for the first time that transcriptional crosstalk between CREB and cFos/cJun at the CRE2/AP-1 motif negatively modulates StARgene expression through nonclassical mechanisms.

\section{Materials and methods}

\section{Generation of StAR promoters and mutagenesis}

Deletion studies have demonstrated that the $5^{\prime}$ flanking $-151 /-1 \mathrm{bp}$ region of the mouse StAR promoter is sufficient for full cAMP responsiveness when compared with the $\sim 3.6 \mathrm{~kb}$ promoter (WootonKee \& Clark 2000, Manna et al. 2002b, 2003a, 2004). This region was synthesized using a PCR-based cloning strategy and sub-cloned into the pGL3 basic vector (Promega Corporation Inc.) utilizing a Xho I and Hind III fragment that contains the firefly luciferase gene as a reporter (Manna et al. 2002b, $2003 b$ ). Using the $-151 /-1 \mathrm{bp}$ fragment, mutations in the single/double CRE and/or AP-1 elements were generated with the Quikchange site-directed mutagenesis kit (Stratagene, La Jolla, CA, USA) and religated into the pGL3 as an Xho I and Hind III fragment. The sense strands of the oligonucleotide sequences (mutated (Mut) bases in boldface lowercase letters) used were: -151/-1 CRE1 Mut, 5'-GGCAATCATTCCATCCTTccggaTCTGCACAATGAC-3'; $\quad-151 /-1$ CRE2/AP-1 Mut, 5'-CCTTGACCCTCTGCACAAT agaTctTGACTTTTTTATCTC-3'; and $-151 /-1$ CRE3 Mut, 5'-CCCTCTGCACAATGACTGAgatCTTTTTTATCTC-3'. Mutations generated in the CRE and/or AP1 motifs were verified by restriction digestion ( Sau 3AI for CRE1 and $B g l$ II for CRE2/AP-1 and CRE3) and 
confirmed by automated sequencing on a PE Biosystems 310 Genetic Analyzer (ABI PRISM 310, PerkinElmer, Boston, MA, USA) at the Texas Tech University Biotechnology Core Facility.

\section{Preparation of nuclear extracts (NE), and CREB and cFos/cJun proteins}

MA-10 mouse Leydig tumor cells (Ascoli 1981; a generous gift from Dr M Ascoli, University of Iowa College of Medicine, Iowa City, Iowa), grown to $70-80 \%$ confluency in HEPES-buffered Weymouth MB/752 medium containing antibiotics, were used to prepare the $\mathrm{NE}$ utilized in gel retardation assays (Manna et al. 2002b, 2004) according to the procedures of Dignam et al. (1983).

The cDNAs encoding CREB and $\triangle$ CREB (deletion of an Nco I-Kpn I fragment in the $\mathrm{NH}_{2}$ terminus, between amino acids 1 and +198 ; a generous gift from Dr P Sassone-Corsi, Université Louis Pasteur, Strasbourg, France) proteins were cloned into the $\mathrm{T} 7$ expression vector $\mathrm{pET} 11 \mathrm{~d}$, and recombinant proteins were produced in vivo as described previously (Masquilier \& Sassone-Corsi 1992, de Groot et al. 1994, Manna et al. 2003b).

cFos and cJun proteins were prepared by in vitro transcription and translation using the TNT T7 Coupled Reticulocyte Lysate System (Promega) according to the instructions of the manufacturer, under optimized conditions (Tan et al. 1994, Norwitz et al. 2002). In vitro transcribed/translated cFos and cJun proteins were analyzed by $10 \%$ SDS-PAGE, transferred to nitrocellulose membranes, their identities confirmed with appropriate Abs (described below) and used in gel retardation assays.

\section{Electrophoretic mobility shift assay (EMSA)}

EMSA experiments were performed using NE, in vitro translated and bacterially expressed proteins (Masquilier \& Sassone-Corsi 1992, Norwitz et al. 2002, Manna et al. $2002 b, 2004)$. The oligonucleotide probes were engineered and synthesized by heating sense and antisense primers at $65^{\circ} \mathrm{C}$ for $5 \mathrm{~min}$ in annealing buffer $(10 \mathrm{mM}$ Tris-HCl, $100 \mathrm{mM} \mathrm{NaCl}, 1 \mathrm{mM}$ EDTA, $\mathrm{pH} 7 \cdot 5$ ), followed by cooling at room temperature. The sense strands of the oligonucleotide sequences (mutated (Mut) bases in boldface lowercase letters) used were the following: CRE1，5'-GGCTTGACCCTCTGCACAATG-3'; CRE2/ AP-1, 5'-GGTCTGCACAATGACTGATGA-3'; CRE3, 5'-GGCTGATGACCTTTTTTATCTCA-3'; CRE2/AP-1 Mut, 5'-GGACCCTCTGCACAATagaTctTGACTT-3'; consensus CRE (Montminy et al. 1986), 5'-GGAGAGATTGCCTGACGTCAGAGAGCTAG-3'; consensus AP-1 (Angel et al. 1987), 5'-GGCGCTTGATGAGTCAGCCGGAA-3'; and consensus Sp-1 (Dynan \& Tjian 1983), $5^{\prime}$-GGATTCGATCGGGGCGGGGCGAG-3'. The doublestranded oligonucleotides were end-labeled with $\left[\alpha^{32} \mathrm{P}\right]$ -
dCTP (Perkin-Elmer Life Sciences Inc.) using Klenow fillin reaction and purified using spin columns (Manna et al. 2002b, 2004). NE $(12 \mu \mathrm{g})$, in vitro translated $(2 \mu \mathrm{g})$ and recombinant $(1.5 \mu \mathrm{g})$ CREB and $\triangle$ CREB proteins were incubated for $15 \mathrm{~min}$ at room temperature in a $20 \mu \mathrm{l}$ reaction buffer (25 mM Tris-HCl, 1 mM EDTA, $4 \%$ Ficoll, $10 \mathrm{mM}$ dithiothreitol, $2 \mu \mathrm{g}$ poly $\mathrm{dIdC}, 40 \mathrm{ng} / \mu \mathrm{l} \mathrm{BSA}$, and $12 \mathrm{mM} \mathrm{MgCl}_{2}, \mathrm{pH} 7 \cdot 9$ ) before the addition of a ${ }^{32} \mathrm{P}$-labeled probe either alone, or in the presence of unlabeled oligonucleotides. Incubation of in vitro translated and recombinant proteins was carried out with a small amount $(0.5 \mu \mathrm{l})$ of reticulocyte lysate, which has previously been demonstrated to increase the DNA-binding activity of several bZIP transcription factors and its effect appears to be due to the presence of stimulating cofactors in the lysate (Abate et al. 1990, Masquilier \& Sassone-Corsi 1992). When Abs were used, binding reactions were carried out for an additional $45 \mathrm{~min}$ on ice prior to addition of the labeled DNA. DNA-protein binding was then subjected to electrophoresis on $5 \%$ polyacrylamide gels in $0.5 \times \mathrm{TBE}$ buffer (90 mM Tris-borate and $2 \mathrm{mM}$ EDTA, pH 8.3). The gels were dried and DNA-protein complexes were visualized with a phosphor-imaging device (Molecular Dynamics, Sunnyvale, CA, USA).

\section{Western blot analysis}

Immunoblotting studies were carried out using total cellular protein (Jo \& Stocco 2004, Manna et al. 2006a,b). Equal amounts of protein $(22-30 \mu \mathrm{g})$ were solubilized in sample buffer and loaded onto either 10 or $6 \%$ SDS-PAGE (Mini Protean II System, Bio-Rad Laboratories Inc.), as described by Laemmli (1970), with minor modifications (Manna et al. 2002a, 2006b). Electrophoresis was performed at $200 \mathrm{~V}$ for $1 \mathrm{~h}$ and the proteins were electrophoretically transferred onto immuno-blot polyvinylidene difluoride (PVDF) membranes (Bio-Rad). The membranes were incubated overnight at $4{ }^{\circ} \mathrm{C}$ in blocking buffer (Tris-buffered saline containing $0 \cdot 2 \%$ Tween-20 and $4 \%$ Carnation nonfat dry milk) and incubated for $2 \mathrm{~h}$ with primary Abs recognizing phospho-CREB and CREB (Cell Signaling Technology, Beverly, MA, USA), phosphocFos (BioSource International Inc., Camarillo, CA, USA), phospho-cJun (Upstate, Lake Placid, NY, USA), cFos (sc52), cJun (sc-7481), and CBP (sc-7300; Santa Cruz Biotechnology Inc., Santa Cruz, CA, USA). Following incubation with primary Abs, the membranes were washed and incubated with appropriate secondary Abs for $2 \mathrm{~h}$, washed again, and immunodetection of proteins were performed with the Chemiluminescence Imaging Western Lightning Kit (Perkin-Elmer). The membranes were exposed to X-ray films (Marsh Bio Products Inc., Rochester, NY, USA) and the intensity of immunospecific bands was quantified using a computer-assisted image analyzer (Visage 2000, BioImage, Ann Arbor, MI, USA). 


\section{Chromatin immunoprecipitation (ChIP)}

ChIP assays were carried out under optimized conditions using a kit (Upstate/Chemicon, Temecula, CA, USA) following the manufacturer's instructions. In brief, MA-10 cells were treated with $0.5 \mathrm{mM}(\mathrm{Bu})_{2} \mathrm{cAMP}$ for different time periods $(0-240 \mathrm{~min})$. Following treatment, formaldehyde ( $1 \%$ final concentration) was added to cells and incubated for $10 \mathrm{~min}$ at $37^{\circ} \mathrm{C}$ to cross-link DNA and its associated proteins. Cells were washed twice with ice-cold PBS containing a protease inhibitor cocktail (SigmaAldrich), scraped, collected, and resuspended in lysis buffer (1\% SDS, $10 \mathrm{mM}$ EDTA, and $50 \mathrm{mM}$ Tris, $\mathrm{pH} 8 \cdot 1$ ). Cells were then sonicated for seven to nine cycles of $10 \mathrm{~s}$ pulses using a Tekmar Sonic Disruptor (Fisher Scientific, Pittsburgh, PA, USA) and pelleted by centrifugation. The supernatant was collected and diluted 1:10 in ChIP dilution buffer $(0.01 \%$ SDS, $1 \%$ triton X-100, $2 \mathrm{mM}$ EDTA, $500 \mathrm{mM} \mathrm{NaCl}$, and $20 \mathrm{mM}$ Tris-HCl, $\mathrm{pH} 8 \cdot 1$ ). To reduce nonspecific background, the chromatin solution was cleared with protein A agarose/salmon sperm DNA $50 \%$ slurry for $30 \mathrm{~min}$ at $4{ }^{\circ} \mathrm{C}$ with agitation. After centrifugation ( $1000 \mathrm{~g}$ for $1 \mathrm{~min}$ ), the supernatant fraction was immunoprecipitated with $4 \mu \mathrm{g}$ specific Abs (as above) to P-CREB, P-cJun, P-cFos, and CBP (Upstate) for $14 \mathrm{~h}$ at $4{ }^{\circ} \mathrm{C}$ with rotation. Immunoglobulin (IgG) and no Ab-treated groups were used as negative controls. Protein A agarose/salmon sperm (50\% slurry) was added and incubated for an additional $1 \mathrm{~h}$. The chromatinantibody-protein A agarose complexes were subsequently washed with low-salt, high-salt, $\mathrm{LiCl}$, and Tris/EDTA buffers according to the manufacturer's instructions. Protein-DNA complexes were eluted with freshly made elution buffer (1\% SDS and $0 \cdot 1 \mathrm{M} \mathrm{NaHCO}_{3}$ ) following rotation at room temperature for $15 \mathrm{~min}$. $\mathrm{NaCl}(5 \mathrm{M})$ was added to the eluates before heating the mixture at $65^{\circ} \mathrm{C}$ for $4 \mathrm{~h}$ to reverse the formaldehyde cross-linking. The resulting samples were treated with $0.5 \mathrm{M}$ EDTA, $1 \mathrm{M}$ Tris$\mathrm{HCl}, \mathrm{pH} 6 \cdot 5$, and proteinase $\mathrm{K}(10 \mathrm{mg} / \mathrm{ml})$ for $1 \mathrm{~h}$ at $45^{\circ} \mathrm{C}$, and the DNA samples were purified by phenol/chloroform extraction and ethanol precipitation, and used for PCR. PCR was performed with the purified DNA sample $(70-80 \mathrm{ng})$ and the proximal mouse StAR promoter primers (forward, 5'-CTGGTCCTCCCTTTACACAGTC$3^{\prime}$, and reverse, $5^{\prime}$-GGCGCAGATCCAGTGCGCTGC-3'), spanning bases $-170 /-149$ and $-21 /-1$ respectively (Caron et al. 1997a). A second primer combination (forward, 5'-GTGAGGACAGCTCATACGTGCAC-3' (bases - 3596/ - 3574) and reverse, 5'-GAACAGGCTTAAGTTAAGACTCC-3' (bases - 3450/-3428)) recognizing the distal region of the mouse StAR promoter was used as a control. PCR was carried out in a $50 \mu \mathrm{l}$ reaction mixture containing $1 \mathrm{nM}$ of each primer, $200 \mu \mathrm{M}$ dNTPs including $\left[\alpha^{32} \mathrm{P}\right]$-CTP and $5 \mathrm{U}$ Taq DNA polymerase in a $1 \times$ PCR buffer under optimized conditions: $95^{\circ} \mathrm{C}$ for $2 \mathrm{~min}$, followed by 36 cycles at $95^{\circ} \mathrm{C}$ for $45 \mathrm{~s}, 58^{\circ} \mathrm{C}$ for $45 \mathrm{~s}$, and $72^{\circ} \mathrm{C}$ for $60 \mathrm{~s}$ (PTC-100, MJ Research Inc., Waltham, MA, USA). A final cycle of extension at $72{ }^{\circ} \mathrm{C}$ for $4 \mathrm{~min}$ was also included. PCR products were determined on $2 \%$ agarose gels. Gels were vacuum dried, exposed to X-ray film (Marsh Bio Products) for 3-5 h, and the resulting signals were quantified (Visage 2000).

\section{Quantitative RT-PCR}

Total RNA was extracted using Trizol reagent (Invitrogen Life Technologies). Mouse StAR cDNA was amplified utilizing the following primer pairs: forward, $5^{\prime}$-GACCTTGAAAGGCTCAGGAAGAAC- $3^{\prime}$, and reverse, $5^{\prime}$-TAGCTGAAGATGGACAGACTTGC- $3^{\prime}$ as described previously (Manna et al. 1999, 2002a, 2006a). The variation in RT-PCR efficiency was assessed with L19 ribosomal protein gene using the forward primer, 5'-GAAATCGCCAATGCCAACTC- $3^{\prime}$, and the reverse primer, $5^{\prime}$-TCTTAGACCTGCGAGCCTCA- $3^{\prime}$. The cDNAs generated were further amplified by PCR using the primer pairs listed above. The molecular sizes of StAR and L19 were determined on $1.2 \%$ agarose gels, which were then vacuum dried, exposed to X-ray film (Marsh Bio Products) for 3-5 h, and the resulting StAR and L19 signals were analyzed.

\section{Plasmids, transfections, and luciferase assays}

StAR reporter plasmids were constructed as described above. CREB (Manna et al. 2002b, 2003b), cFos (Manna et al. 2004), and cJun (Manna et al. 2004) plasmids have been described previously. The pRL-SV40 plasmid containing the Renilla luciferase gene driven by SV40 promoter was purchased from Promega. CBP (Kwok et al. 1994), E1A and mutant ( $\Delta 2-36)$ E1A (Stein et al. 1990, Ray et al. 2002) expression plasmids were obtained from Dr P Sassone-Corsi and Dr A R Brasier (The University of Texas Medical Branch, Galveston, Texas, USA) respectively.

MA-10 cells were transfected using FuGENE 6-transfection reagent (Roche Diagnostics Corp.) under optimized conditions (Manna et al. 2003b, 2004). In brief, the $-151 /-1$ StAR reporters (wild type and mutants) were transfected in the absence or presence of different expression plasmids (1:1). The amount of DNA used in transfections was equalized with empty vector. Transfection efficiency was normalized by co-transfecting 10 $20 \mathrm{ng}$ pRL-SV40 vector (a plasmid that constitutively expresses renilla luciferase).

Luciferase activity in the cell lysates was determined by the Dual-luciferase reporter assay system (Promega). Following treatments, cells were washed with $0 \cdot 01 \mathrm{M}$ PBS and $300 \mu \mathrm{l}$ reporter lysis buffer were added to the plates. Cellular debris was pelleted by centrifugation at $12000 \mathrm{~g}$ at $4^{\circ} \mathrm{C}$, and the supernatant was measured for relative light units (RLU) using a TD 20/20 Luminometer (Turner Designs, Sunnyvale, CA, USA). 


\section{Statistical analysis}

All experiments were repeated at least thrice. Statistical analysis was performed using ANOVA using Statview (Abacus Concepts Inc., Berkeley, CA, USA) followed by Fisher's protected least significant differences test. Data represent the mean \pm s.E.M. and $P<0.05$ was considered significant.

\section{Results}

\section{Interaction of CRE and AP-1 DNA-binding proteins with the StAR promoter}

We have previously identified three CRE-like sites in the mouse StAR promoter, of which the CRE2 element is analogous to an AP-1 sequence (CRE2/AP-1), suggesting crosstalk may occur between CRE and AP-1 DNA-binding proteins in StAR's transcriptional regulation (Manna et al. $2002 b, 2004)$. To determine whether these factors interact with the CRE2/AP-1 region, EMSA reactions were performed using NE obtained from $(\mathrm{Bu})_{2} \mathrm{cAMP}$-treated $(0.5 \mathrm{mM}, 6 \mathrm{~h}) \mathrm{MA}-10$ cells. As illustrated in Fig. $1, \mathrm{a}{ }^{32} \mathrm{P}-$ labeled CRE2/AP-1 probe resulted in the formation of two prominent DNA-protein complexes that were markedly decreased in the presence of unlabeled competitor (compare lanes 2 and 3). Unlabeled consensus (Con) CRE (lanes 4-6) and AP-1 (lanes 7-9) oligomers competed for binding to ${ }^{32}$ P-labeled CRE2/ AP-1 in a concentration-dependent manner. In previous studies from our laboratory, we demonstrated that among the different antibodies (Abs) to CREB/CREM and Fos/ Jun that were examined, CREM, cFos, and Fra-2 Abs markedly decreased DNA-protein binding (Manna et al. 2002b, 2004). However, DNA-protein complexes were not affected by an oligomer (lanes 10 and 11) bearing the unrelated Sp-1-binding site, demonstrating the specificity of interaction of both CRE and AP-1 DNA-binding proteins with the CRE2/AP-1 sequence.

The ability of the CRE2/AP-1 motif to bind CRE and AP-1 family proteins, specifically CREB, cFos, and cJun, was assessed using EMSA. A ${ }^{32}$ P-labeled CRE2/AP-1 probe demonstrated the presence of a specific complex with recombinant CREB (lanes 2 and 3 ) and in vitro translated cFos (lanes 4 and 5) and cJun (lanes 6 and 7) proteins (Fig. 2). The Abs that recognize CREB, cFos, and cJun in immunoblots markedly inhibited DNAprotein complex formation. These findings corroborate the preceding results (Fig. 1) and indicate that both CRE and AP-1 family proteins can specifically bind to the CRE2/AP-1 motif.

The involvement of CRE1 and CRE3 on CREB and cFos/cJun-protein binding was investigated next. The results presented in Fig. 3 demonstrate that ${ }^{32} \mathrm{P}$-labeled CRE1 (Fig. 3A) and CRE3 (Fig. 3B) probes bind CREB (lanes 2 and 3) protein, but not cFos (lane 4) or cJun (lane 5), indicating that these sites do not recognize the AP-1 family proteins. Also, CREB Ab markedly inhibited formation of the CRE1- and CRE3CREB binding (Fig. 3).

\section{$(\mathrm{Bu})_{2}$ CAMP enhances CREB, cFos, and cJun phos- phorylation and CBP association with the StAR promoter}

MA-10 cells treated with $(\mathrm{Bu})_{2}$ cAMP for $0-240 \mathrm{~min}$ resulted in enhanced phosphorylation of CREB (P-CREB) within 5 min $(P<0 \cdot 05)$, reached maximal levels by $15 \mathrm{~min}(6 \cdot 1 \pm 1 \cdot 2$-fold $)$, and did not change thereafter up to $240 \mathrm{~min}$ (Fig. 4A and D). Under similar experimental paradigms, P-cFos and cFos peaked at 30 min with increases of $4 \cdot 2$ - and $3 \cdot 7$-fold over basal respectively and decreased thereafter with time. P-cFos fell to below control levels by 120-240 min (Fig. 4B and D). P-cJun was elevated by $10 \mathrm{~min}(P<0 \cdot 05)$, reached $4 \cdot 5 \pm 0 \cdot 6$-fold by $15-30 \mathrm{~min}$, and decreased below controls at 60-240 min (Fig. 4C and D). No alteration in the amounts of CREB and cJun proteins was observed during the time course studied. While treatment with $(\mathrm{Bu})_{2} \mathrm{cAMP}$ induced both phosphorylation and expression of $\mathrm{cFos}$, the alteration in the levels of P-CREB and P-cJun reflected increases in protein phosphorylation rather than protein synthesis.

To determine whether increased phosphorylation of CREB, cFos, and cJun recruits the coactivator CBP to the StAR promoter, ChIP assays were performed (Fig. 5). $(\mathrm{Bu})_{2}$ cAMP-treated, cross-linked, sheared chromatin was immunoprecipitated with either phospho-specific CREB, cFos, and cJun or CBP Abs, and recovered DNA was subjected to quantitative PCR analysis amplifying the proximal ( $-170 /-1$ bp encompassing the CRE2/AP-1 motif) and the distal ( $-3596 /-3428 \mathrm{bp})$ regions of the StAR promoter. The results demonstrate that within 30 min, $(\mathrm{Bu})_{2} \mathrm{CAMP}$ increased association of P-CREB $(3 \cdot 6 \pm 0 \cdot 5$-fold $)$, P-cFos $(3 \cdot 4 \pm 0 \cdot 4$-fold $)$, P-cJun $(2 \cdot 9 \pm$ $0 \cdot 3$-fold $)$, and CBP $(3 \cdot 8 \pm 0 \cdot 6$-fold $)$ with the proximal (Fig. 5A), but not with the distal (Fig. 5B), region of the StAR promoter. However, no signal was observed with DNA recovered from IgG or no Ab-treated groups. Additionally, $(\mathrm{Bu})_{2}$ cAMP was able to increase P-CREB, $\mathrm{P}-\mathrm{cF}$ os, and P-CJun association with the StAR promoter in a temporal manner (Fig. 5C). While increased association of P-cFos and P-cJun decreased by $240 \mathrm{~min}$, the induction was sustained for P-CREB, resulting in a high $\mathrm{P}$-CREB to $\mathrm{P}$-cFos / P-cJun ratio at $4 \mathrm{~h}$. CBP association in response to $(\mathrm{Bu})_{2} \mathrm{cAMP}$ (Fig. 5C) was found to be qualitatively similar to those of P-CREB, indicating the physical interaction of P-CREB-DNA during CBP recruitment to the StAR promoter. Levels of CBP protein in $(\mathrm{Bu})_{2}$ cAMP-treated MA-10 cells were unaltered during this time period (data not shown). 


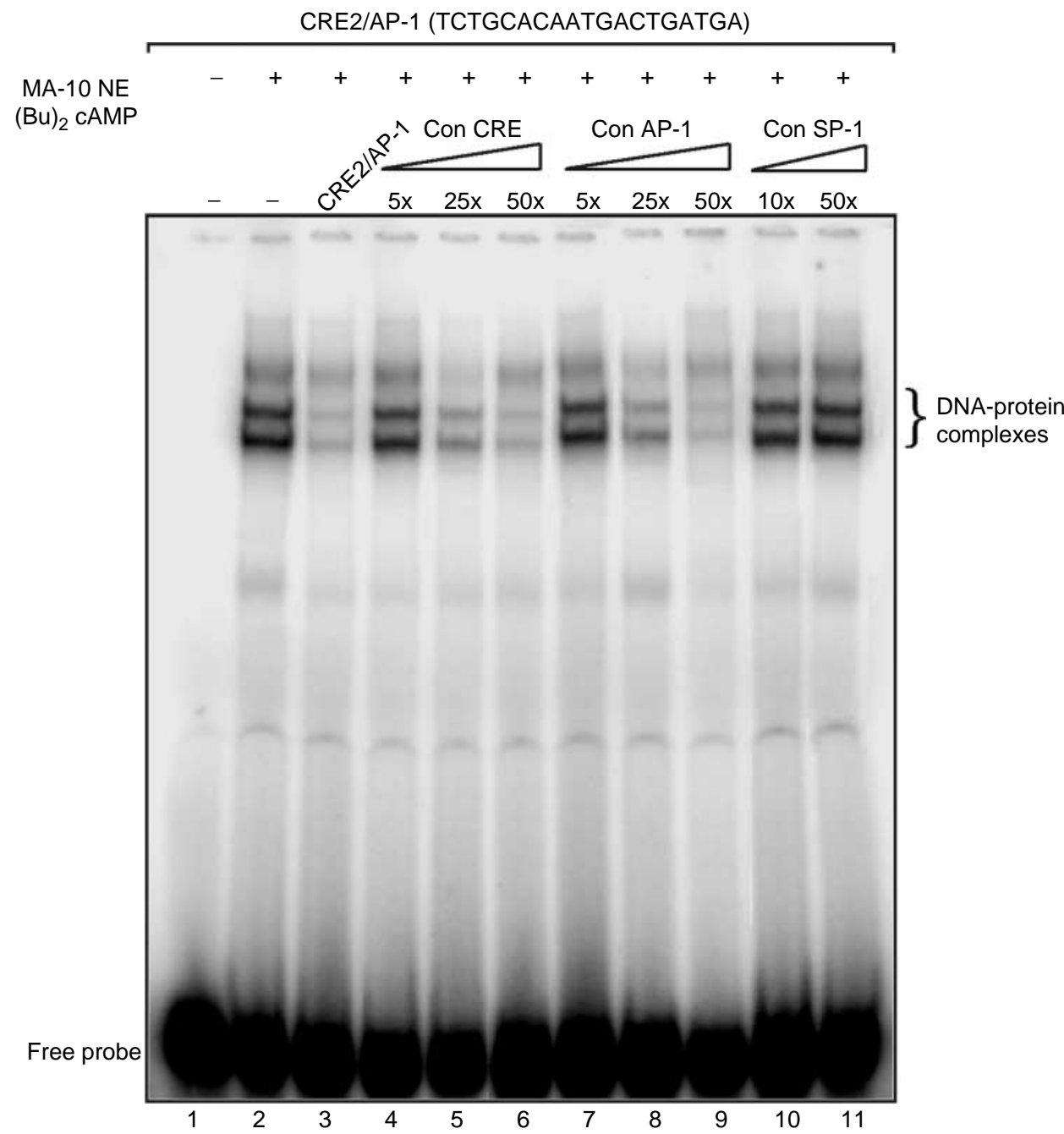

Figure 1 Interaction of CRE and AP-1 DNA-binding proteins with the CRE2/AP-1 motif in MA-10 cells. EMSA was performed to assess interaction of CRE and AP-1 DNA-binding proteins using a double-stranded oligonucleotide probe encompassing the CRE2/AP-1 region of the StAR promoter as described in Materials and methods section. Nuclear extracts $(\mathrm{NE}, 12 \mu \mathrm{g})$ obtained from $(\mathrm{Bu})_{2} \mathrm{CAMP}$-stimulated $(0.5 \mathrm{mM}, 6 \mathrm{~h}) \mathrm{MA}$ 10 cells were used to determine protein binding to the ${ }^{32} \mathrm{P}$-labeled CRE2/AP-1 motif (lanes 1-11) in the absence or presence of 5-/10-, 25-, and 50-fold excess of unlabeled consensus (Con) CRE (lanes 4-6), AP-1 (lanes 7-9), and Sp-1 (lanes 10 and 11) sequences. Binding of CRE2/AP-1 DNA to MA-10 NE was assessed with 50-fold excess of unlabeled probe (lanes 2 and 3). A representative phosphor image illustrates DNAprotein complexes in different groups. Migration of free probe is shown for each lane. DNA-protein complexes were resolved on $5 \%$ polyacrylamide gels, the gels dried, and the complexes visualized with a phosphor-imaging device. Data are representative of three independent experiments.

\section{Interactions of CREB and cFos/cJun with the CRE2/AP-1 motif and the consequences on StAR gene expression}

Since CREB, cFos, and cJun were found to bind to the shared CRE2/AP-1 element, their interactions on StAR promoter responsiveness were investigated (Fig. 6). The utilization of the $-151 /-1$ bp StAR luciferase reporter construct (Fig. 6A) was based on previous studies (Manna et al. 2002b, 2003b, 2004). MA-10 cells transfected with the
$-151 /-1$ StAR segment showed a $3 \cdot 9 \pm 0 \cdot 4$ fold increase in $(\mathrm{Bu})_{2} \mathrm{CAMP}$-stimulated reporter activity over basal (Fig. 6B). Expression of CREB increased basal and $(\mathrm{Bu})_{2-}$ cAMP-induced StAR promoter activity over the response seen in mock-transfected (pcDNA3) cells. While cFos and cJun were capable of activating basal promoter activity, they diminished $(\mathrm{Bu})_{2} \mathrm{CAMP}$-induced fold responsiveness when compared with controls (Manna et al. 2004). Notably, coexpression of CREB with either cFos or cJun repressed both basal and $(\mathrm{Bu})_{2}$ cAMP-mediated StAR reporter activity 


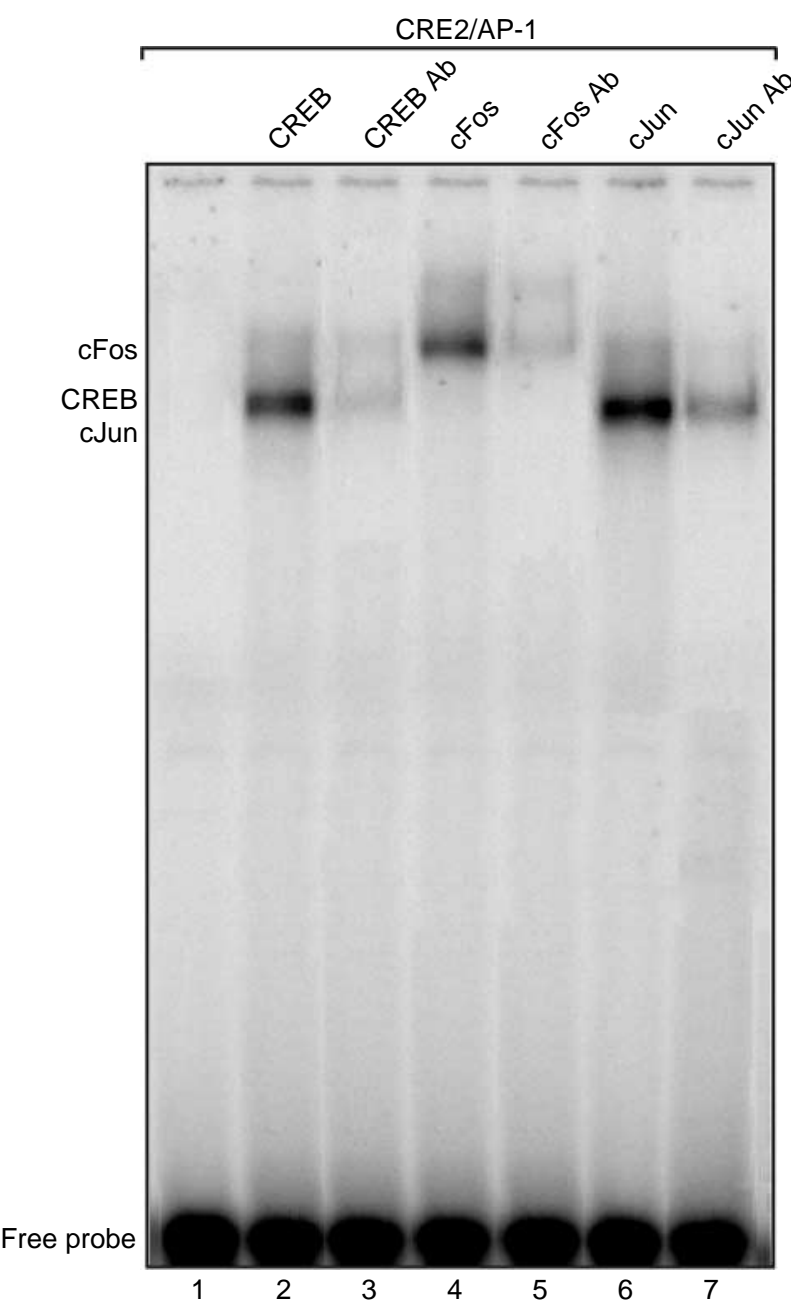

Figure 2 Binding of CREB, cFos, and cJun proteins to CRE2/AP1 sequence. DNA-binding activity of recombinant CREB $(1.5 \mu \mathrm{g})$ and in vitro translated $(2 \mu \mathrm{g}) \mathrm{cFos}$ and cJun proteins were evaluated with the double-stranded ${ }^{32} \mathrm{P}$-labeled CRE2/AP-1 probe. EMSA reactions were carried out as described in the legend of Fig. 1. A representative phosphor image illustrates formation of a DNA-protein complex and $A b$ interference analysis with CREB (lanes 2 and 3), cFos (lanes 4 and 5), and cJun (lanes 6 and 7). Bands corresponding to specific binding by CREB, cFos, and cJun are labeled. Migration of free probes is shown for each lane. These experiments were repeated three to four times.

when compared with their response individually, suggesting a competition between the two families of proteins.

The specificity of the CRE2/AP-1 site on CREB and cFos/cJun-mediated repression was investigated by disrupting the CRE2/AP-1 motif (TGACTGA to TagaTct). As shown in Fig. 7A, MA-10 cells transfected with the $-151 /-1$ StAR bearing a mutation in the CRE2/AP-1 motif showed an $\sim 50 \%$ decrease in basal reporter activity without affecting the $(\mathrm{Bu})_{2} \mathrm{CAMP}$ response. CREB responsiveness was attenuated by $40-53 \%$. Utilizing this mutant, the inhibitory effects of $\mathrm{cFos}$ and cJun on $(\mathrm{Bu})_{2} \mathrm{cAMP}-$
A
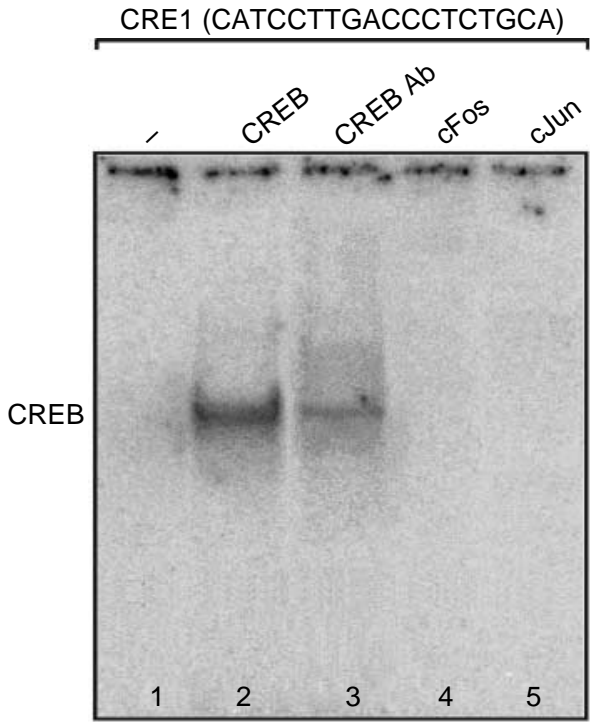

B
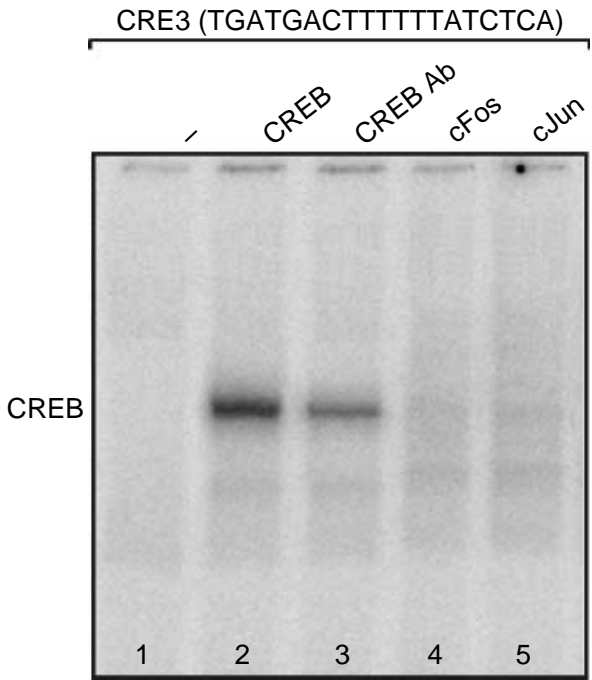

Figure 3 Binding of CREB, cFos, and cJun proteins to CRE1 and CRE3 sites. DNA-binding studies were performed using doublestranded oligonucleotide probes corresponding to (A) CRE1 (lanes 1-5) and (B) CRE3 (lanes 1-5) elements in the StAR promoter as described in the legend of Fig. 1. Representative phosphor images illustrate formation of a specific DNA-protein complex with CREB and its interference with CREB Ab (lanes 2 and 3). No binding of cFos (lane 4) and cJun (lane 5) proteins to CRE1 and CRE3 sites was observed. Data are representative of three separate experiments.

mediated StAR promoter activity were lost, demonstrating the importance of the CRE2/AP-1 motif on CREB and Fos/Jun activity. The contributions of the CRE1 and CRE3 sites were also examined using mutational analysis. Transfection of cells with the $-151 /-1$ StAR segment containing disrupted CRE1 (TGACCCT to TccggaT) and CRE3 (TGACTTT to gatCTTT) sites, within the context of an intact CRE2/AP-1 motif, inhibited basal StAR reporter 


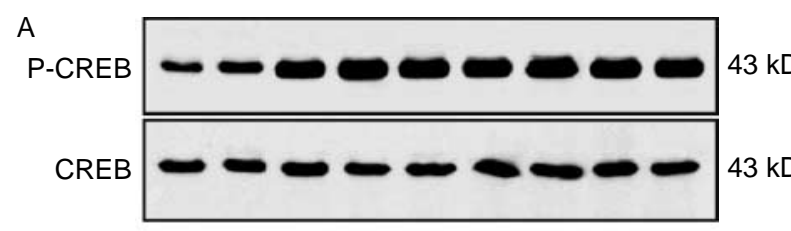

B
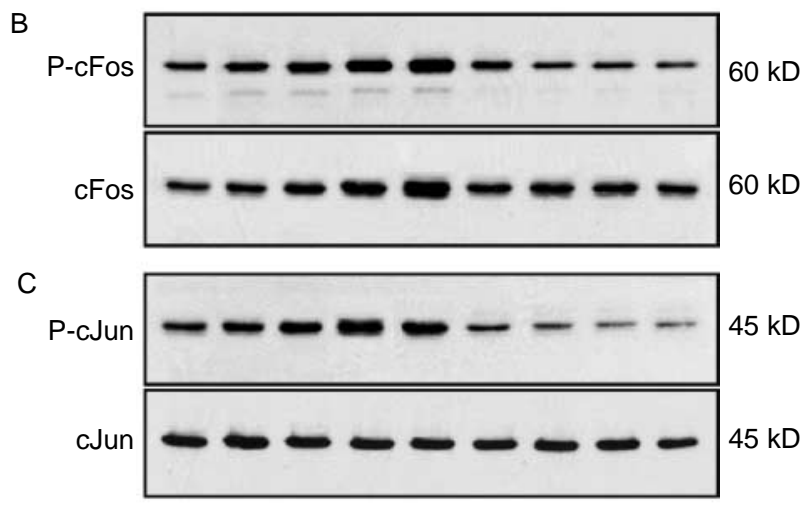

D

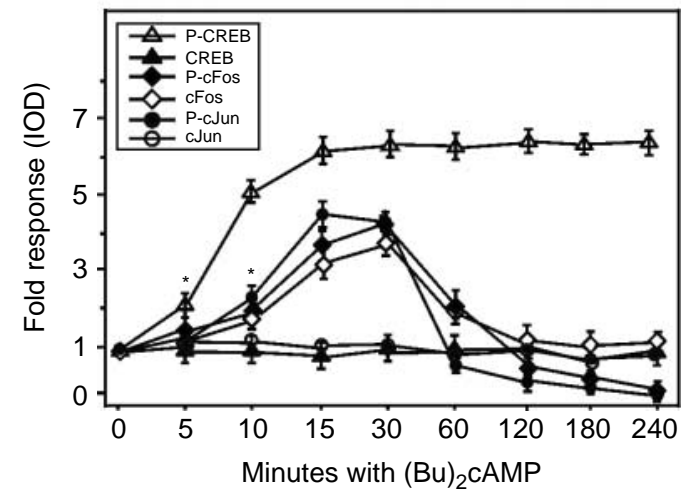

Figure 4 Phosphorylation and expression of CREB, cFos, and cJun in response to $(\mathrm{Bu})_{2} \mathrm{CAMP}$. MA-10 cells were treated with $0.5 \mathrm{mM}(\mathrm{Bu})_{2} \mathrm{cAMP}$ for $0-240 \mathrm{~min}$, and $25-30 \mu \mathrm{g}$ total protein were used for determining phosphorylation $(P)$ and expression of $(A)$ CREB, (B) cFos, and (C) cJun by western blotting. Representative immunoblots illustrate phosphorylation (upper panels) and expression (lower panels) of CREB, cFos, and cJun in response to $(\mathrm{Bu})_{2} \mathrm{cAMP}$. Integrated optical density (IOD) values of each band were quantified and the compiled data presented in terms of (D) fold response, which represent the mean \pm S.E.M. of three to four independent experiments. ${ }^{\star} P<0.05$ vs 0 min (control).

activity by $\sim 70 \%$ but did not affect $(\mathrm{Bu})_{2}$ cAMP-mediated responsiveness (Fig. 7B). cFos and cJun resulted in decreases in $(\mathrm{Bu})_{2}$ cAMP-stimulated StAR reporter activity when compared with controls. Importantly, CREB and cFos/cJun coexpression diminished both basal and $(\mathrm{Bu})_{2} \mathrm{cAMP}-$ mediated StAR promoter activity, indicating that the CRE2/AP-1 motif plays an obligatory role in CREB- and Fos/Jun-mediated suppression of StAR gene transcription.

CREB and cFos/cJun protein binding to the CRE2/AP-1 DNA was assessed by EMSA-binding competition experiments by generating a truncated form of CREB ( $\triangle \mathrm{CREB})$, since the CREB dimer migrates at a similar
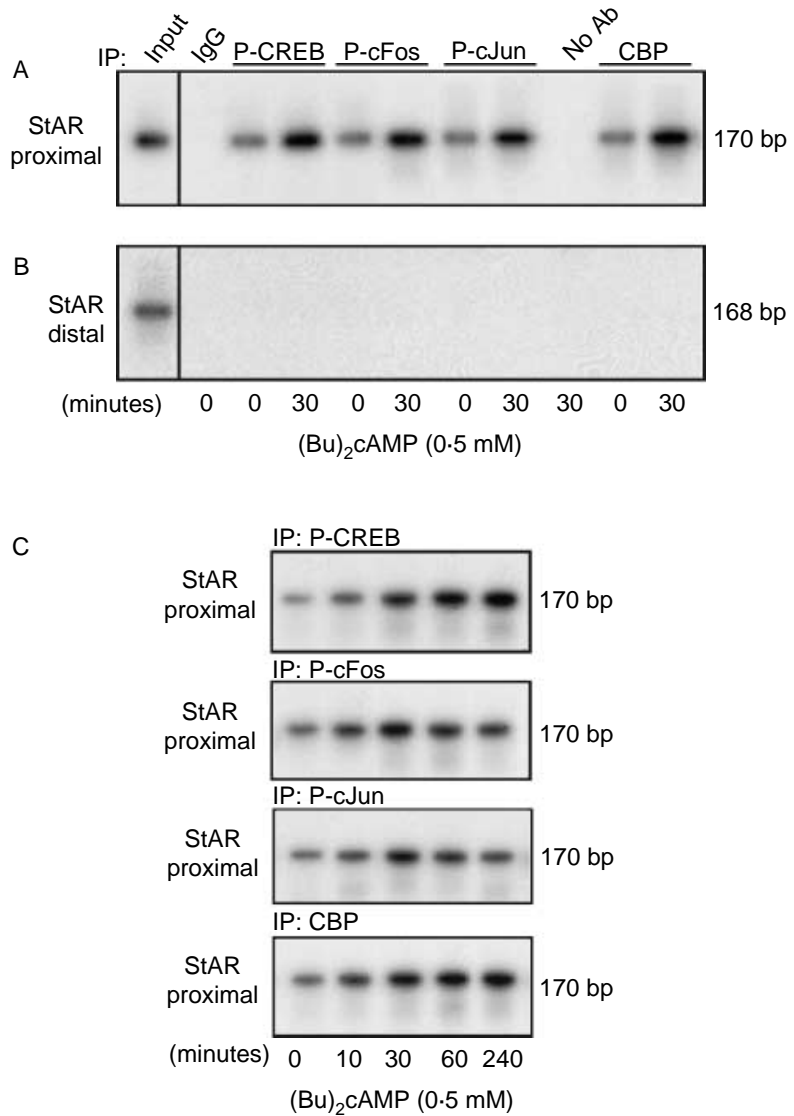

Figure 5 Effect of $(\mathrm{Bu})_{2}$ CAMP on P-CREB, P-cFos, P-cJun, and $\mathrm{CBP}$ association with the StAR promoter. MA-10 cells were treated without or with $0.5 \mathrm{mM}(\mathrm{Bu})_{2} \mathrm{CAMP}$ for 0-240 min (as indicated) and ChIP assays were carried out as described in Materials and methods section. Cross-linked sheared chromatin obtained from $(\mathrm{Bu})_{2} \mathrm{CAMP}$ treatments was immunoprecipitated (IP) without (no Ab) or with IgG, anti-P-CREB, anti-P-cFos, anti-PcJun, and anti-CBP Abs. Recovered chromatin was subjected to PCR analysis using primers $(-170 /-1 \mathrm{bp})$ encompassing the CRE2/AP-1 region of the StAR promoter and primers (3596/3428 bp) $\sim 3500$ bp upstream of the CRE2/AP-1 region. Representative autoradiograms illustrate association of $\mathrm{P}$-CREB, $\mathrm{P}$ cFos, P-cJun, and CBP to the StAR promoter in response to $(\mathrm{Bu})_{2} \mathrm{CAMP}$ (A and B: 0 or $30 \mathrm{~min}$; C: 0-240 min). Data are representative of three independent experiments.

position as the Fos/Jun heterodimer in a non-denaturing gel. As illustrated in Fig. 8A, a ${ }^{32}$ P-labeled consensus (Con) CRE probe could bind to full-length (lanes 2-4) and $\triangle$ CREB (lanes 5-7) proteins, and the DNA-protein complex in both cases was strongly inhibited by CREB $\mathrm{Ab}$ (lanes 4 and 7), demonstrating the integrity of the $\triangle$ CREB protein. However, it can be clearly seen that addition of increasing amounts of $\triangle$ CREB $(0-1200 \mathrm{ng}$, lanes 2-7) with a fixed amount of in vitro transcribed/ translated cFos/cJun ( $2 \mu \mathrm{g})$ resulted in decreases in Fos/ Jun binding to the CRE2/AP-1 site in a concentrationdependent manner (Fig. 8B). These data indicate that both CREB and cFos/cJun dimers bind and compete with 
A

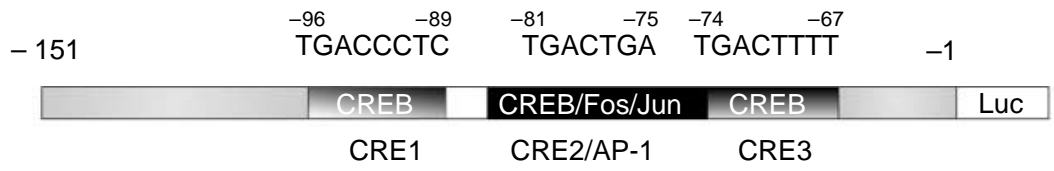

StAR promoter reporter construct

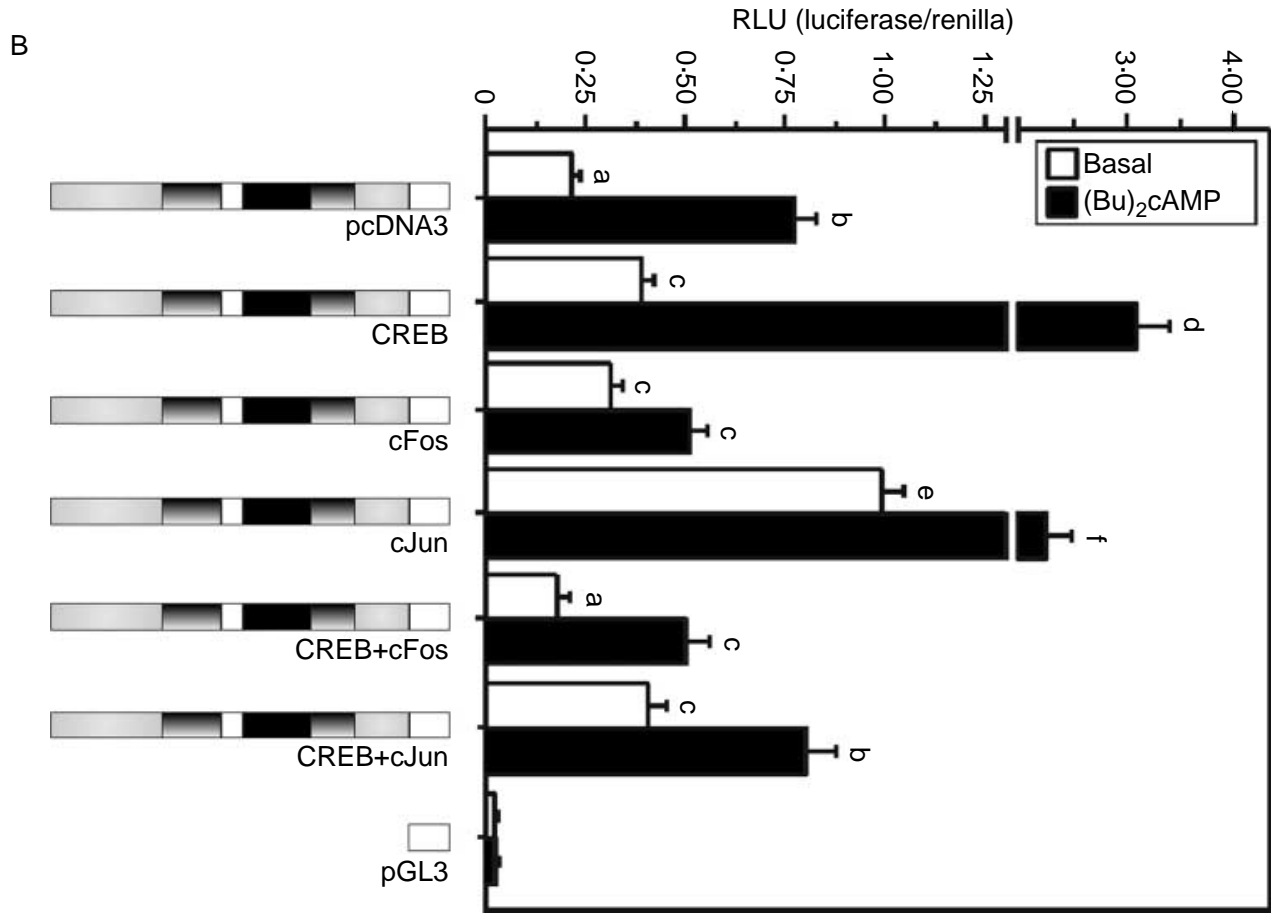

Figure 6 Effects of CREB, cFos, and cJun on StAR promoter responsiveness. (A) Schematic representation of the $-151 /-1 \mathrm{bp}$ region of the StAR promoter reporter plasmid illustrating the position and sequences of $C R E$ and/or AP-1 elements binding to putative transcription factors. (B) MA-10 cells were transfected with empty vector (pcDNA3), CREB, cFos, and cJun expression plasmids, or a combination of them as indicated, in the presence of the $-151 /-1$ StAR reporter segment. pGL3 basic (pGL3) was used as a control. To control for variation in transfection efficiency, pRL-SV40 was included in each incubation. Following $36 \mathrm{~h}$ of transfection, cells were incubated for a further $6 \mathrm{~h}$ in the absence (Basal) or presence of $0.5 \mathrm{mM}(\mathrm{Bu})_{2} \mathrm{CAMP}$, and luciferase activity in the cell lysates was determined and expressed as relative light units (RLU, luciferase/renilla). Data represent the mean \pm S.E.M. of four independent experiments. Letters above the bars indicate that these groups differ significantly at least at $P<0.05$.

each other for the CRE2/AP-1 motif and result in attenuation of StAR gene expression.

\section{Functional involvement of CBP in transcription of the StAR gene}

To understand the molecular events involved in CREBand cFos/cJun-mediated repression of the StAR gene, the involvement of CBP was examined since both CREB and cFos/cJun utilize CBP as a coactivator (Kwok et al. 1994, Bannister \& Kouzarides 1995, Clem et al. 2005). The results presented in Fig. 9 show that the increased $(\mathrm{Bu})_{2}$ cAMP-responsive CBP association with the StAR promoter by CREB, cFos, and cJun (in duplicates) were attenuated $(P<0 \cdot 05)$ when CREB was coexpressed with either cFos or cJun (Fig. 9A and B). No signal was observed in IgG-treated groups. CREB and cFos/cJun coexpression were also found to decrease CBP association with the StAR promoter under basal conditions (data not shown). These findings demonstrate that CBP plays an essential role in CREB and cFos/cJunmediated transcription of the StAR gene.

The importance of CBP in StAR transcription was further evaluated using the adenovirus E1A oncoprotein, which binds to the cystein/histidine-rich $(\mathrm{C} / \mathrm{H} 3)$ domain of CBP/p300 and inhibits its function (Arany et al. 1995, Perissi et al. 1999). Figure 10A demonstrates that MA-10 cells transfected with an E1A expression vector, in the 

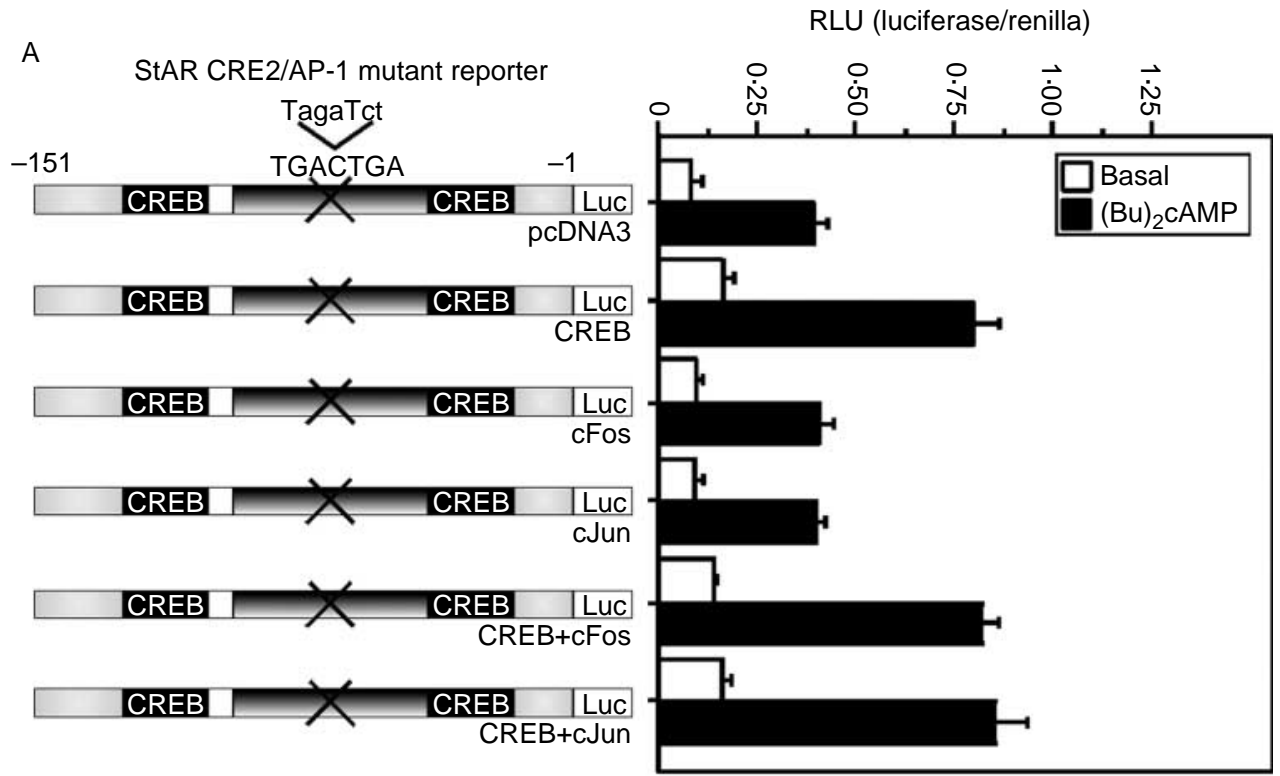

B

StAR CRE1 and CRE3 mutant reporter

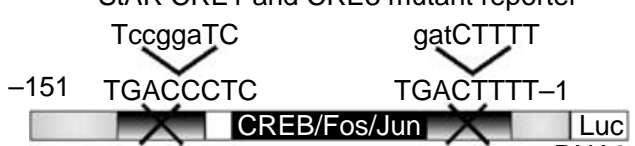

AcDNA3
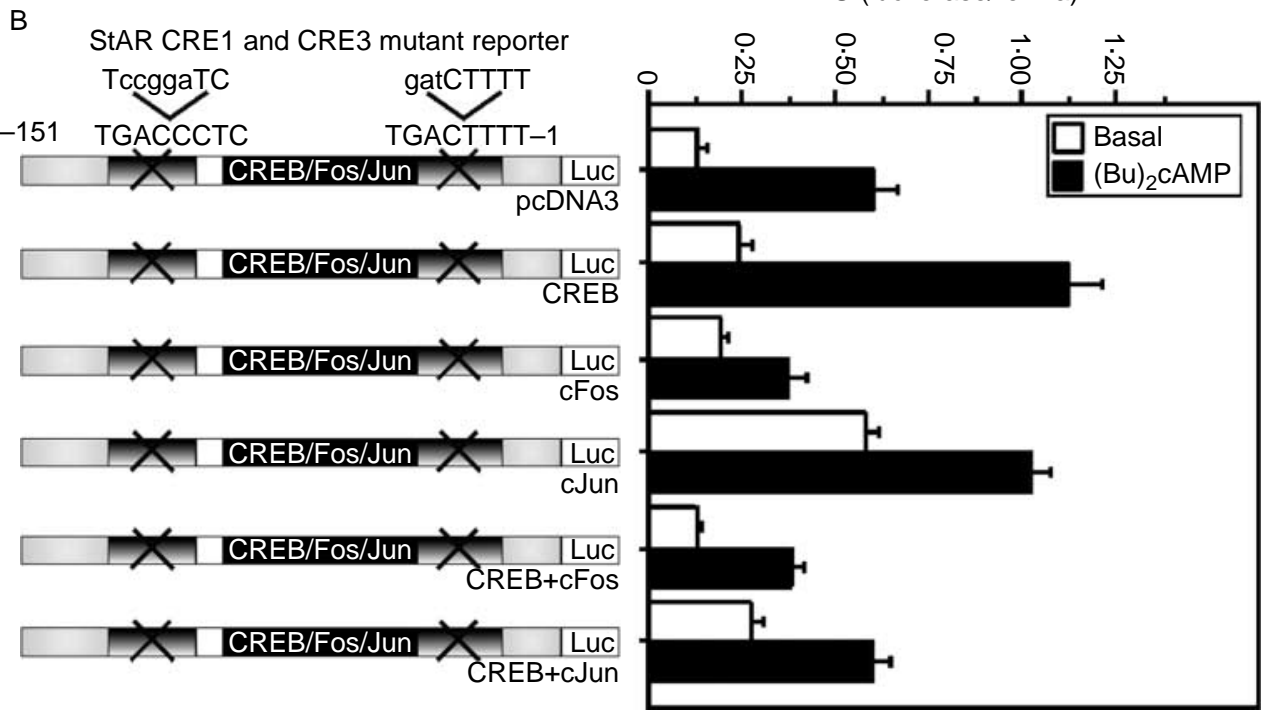

Figure 7 Importance of the CRE2/AP-1 region in CREB-, cFos-, and cJun-mediated StAR promoter activity. MA-10 cells were transfected with empty vector (pcDNA3), CREB, cFos, and cJun or a combination of them as indicated, in the presence of the $-151 /-1$ StAR reporter segment containing mutations in either (A) CRE2/AP-1 or (B) CRE1 and CRE3 sites. The variation in transfection efficiency was assessed with pRL-SV40. Following $36 \mathrm{~h}$ of transfection, cells were incubated for a further $6 \mathrm{~h}$ in the absence (Basal) or presence of $0.5 \mathrm{mM}(\mathrm{Bu})_{2} \mathrm{CAMP}$. Luciferase activity in the cell lysates was determined and expressed as RLU (luciferase/renilla). Schematic representations illustrate the approximate positions of the different elements together with the mutations (mutated bases in lowercase letters) within the $-151 /-1$ bp region. Data represent the mean \pm S.E.M. of three independent experiments.

presence of the $-151 /-1$ StAR reporter segment, markedly repressed $(P<0 \cdot 01)$ StAR promoter activity when compared with a mock transfection (pcDNA3). Expression of a mutant E1A $(\mathrm{M}(\Delta 2-36) \mathrm{E} 1 \mathrm{~A})$, defective in $\mathrm{CBP} / \mathrm{p} 300$ binding, had no apparent effects. CBP protein levels were unaltered in mock, E1A- and $\mathrm{M}(\Delta 2-36)$ E1A-transfected cells (Fig. 10A, inset). Overexpression of $\mathrm{CBP}$, in the presence of $\mathrm{E} 1 \mathrm{~A}$, eliminated 
A

Con CRE (AGAGATTGCCTGACGTCAGAGAGCTAG)

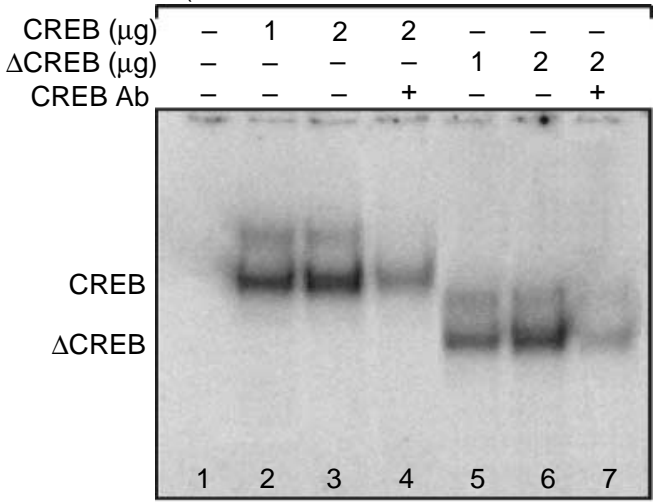

CRE2/AP-1

B

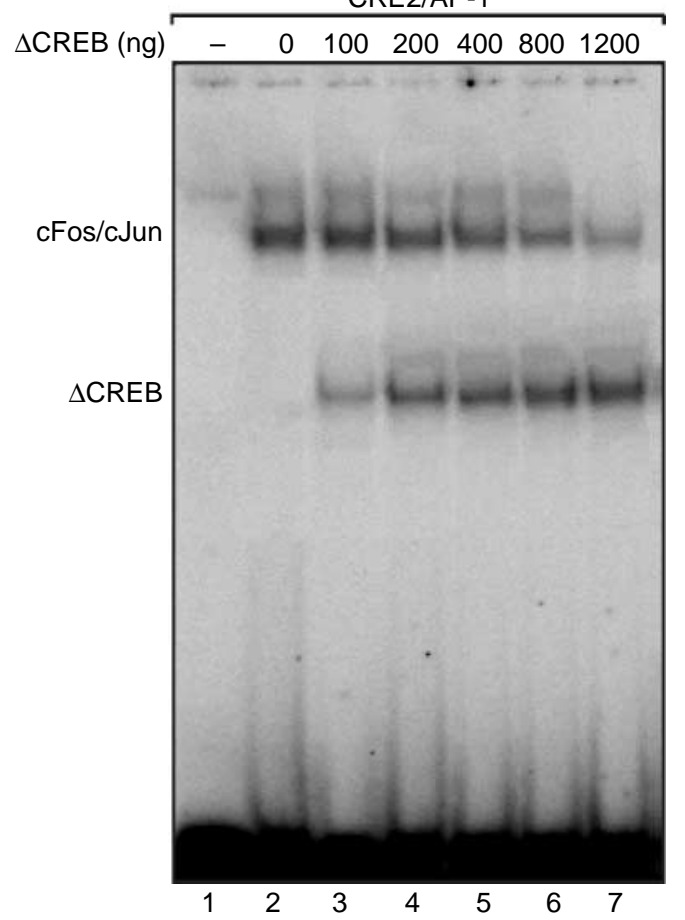

Figure 8 Integrity of truncated CREB and competition between CREB and cFos/cJun proteins for binding to the CRE2/AP-1 site. (A) A radioactively labeled consensus (Con) CRE probe (lanes 1-7) was used for CREB (lanes 2-4) and $\triangle$ CREB (lanes 5-7) protein binding using EMSA. DNA-protein binding was analyzed with CREB Ab (lanes 4 and 7). A representative phosphor image shows the specificity of CREB and $\triangle$ CREB protein $(1-2 \mu \mathrm{g})$ binding to Con CRE sequence. DNA-protein complexes in both cases are indicated. (B) Competition of CREB and CFos/cJun protein binding was assessed using an oligonucleotide probe corresponding to the CRE2/AP-1 region of the StAR promoter. In vitro translated $(2 \mu \mathrm{g})$ cFos/cJun proteins (lanes 2-7) were incubated in the presence of increasing amounts of recombinant $\triangle$ CREB $(0-1200 \mathrm{ng})$ and then DNA-protein binding was carried out as described in the legend of Fig. 1. A representative phosphor image illustrates competition of CREB and cFos/cJun binding to the CRE2/AP-1 motif. DNA-protein complexes in both cases are indicated. Results are representative of three independent experiments.

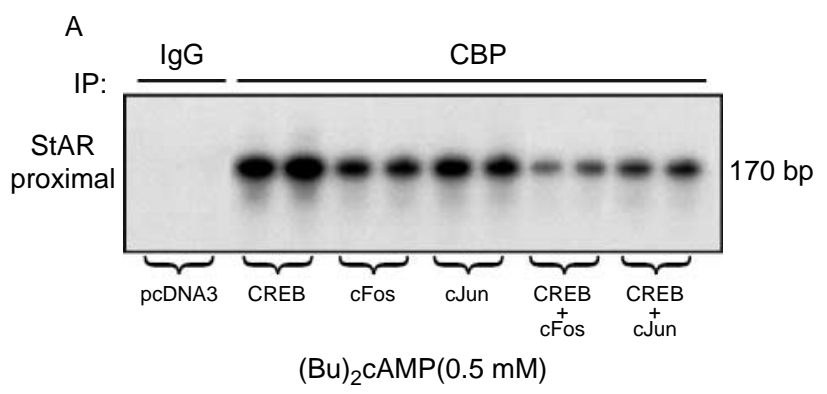

B

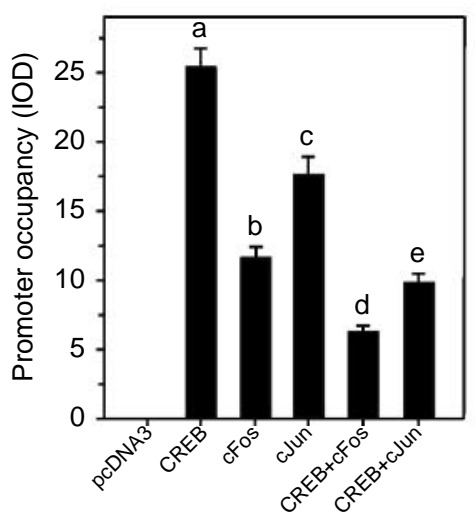

$(\mathrm{Bu})_{2} \mathrm{CAMP}(0.5 \mathrm{mM})$

Figure 9 Overexpression of CREB, cFos, and cJun on CBP recruitment to the StAR promoter. MA- 10 cells were transfected with empty vector (pcDNA3), CREB, cFos, and cJun, or a combination of them in duplicates (as indicated), and ChIP assay was carried out as described in Materials and methods section. Following $48 \mathrm{~h}$ of transfection, cells were treated with $(\mathrm{Bu})_{2} \mathrm{CAMP}(0.5 \mathrm{mM}, 30 \mathrm{~min})$ and processed for ChIP. Cross-linked sheared chromatin obtained from different groups was immunoprecipitated (IP) with IgG or antiCBP Ab. Recovered chromatin was subjected to PCR analysis with primers $(-170 /-1 \mathrm{bp})$ encompassing the CRE2/AP-1 region of the StAR promoter. (A) A representative autoradiogram illustrates association of CBP with the StAR proximal promoter. (B) IOD values of each band were quantified and the compiled data ( \pm S.E.M., $n=3$ ) are presented. Letters above the bars indicate that these groups differ significantly at least at $P<0.05$.

StAR promoter repression, suggesting that the E1Amediated inhibition was due to sequestration of CBP. Qualitatively, similar results were observed when StAR mRNA levels were determined in mock, E1A- and $\mathrm{M}(\Delta 2-36)$ E1A-transfected cells (Fig. 10B). Altogether, these findings demonstrate that the suppression of the StAR gene was due to titration of a limiting amount of endogenous CBP in MA-10 cells.

The role of CBP in CREB and cFos/cJun-responsive StAR promoter activity was studied next. As illustrated in Fig. 10C, ectopic expression of CBP in the presence of CREB, resulted in a $2 \cdot 3 \pm 0 \cdot 4$-fold increase in StAR promoter-driven luciferase activity in response to $(\mathrm{Bu})_{2}$ cAMP over the induction seen with CREB alone. Similarly, the $-151 /-1 \mathrm{bp}$ region of the StAR 
promoter that responds to exogenous cFos and cJun was further stimulated between $1 \cdot 7$ - and $2 \cdot 0$-fold in the presence of $\mathrm{CBP}$, when compared with $(\mathrm{Bu})_{2} \mathrm{cAMP}-$ treated cFos/cJun responsiveness. These findings demonstrate that CBP is a coactivator for both CREB and cFos/cJun, and that the transcriptional interference between these transcription factors appears to be due to competition for binding with limiting amounts of intracellular CBP.

A
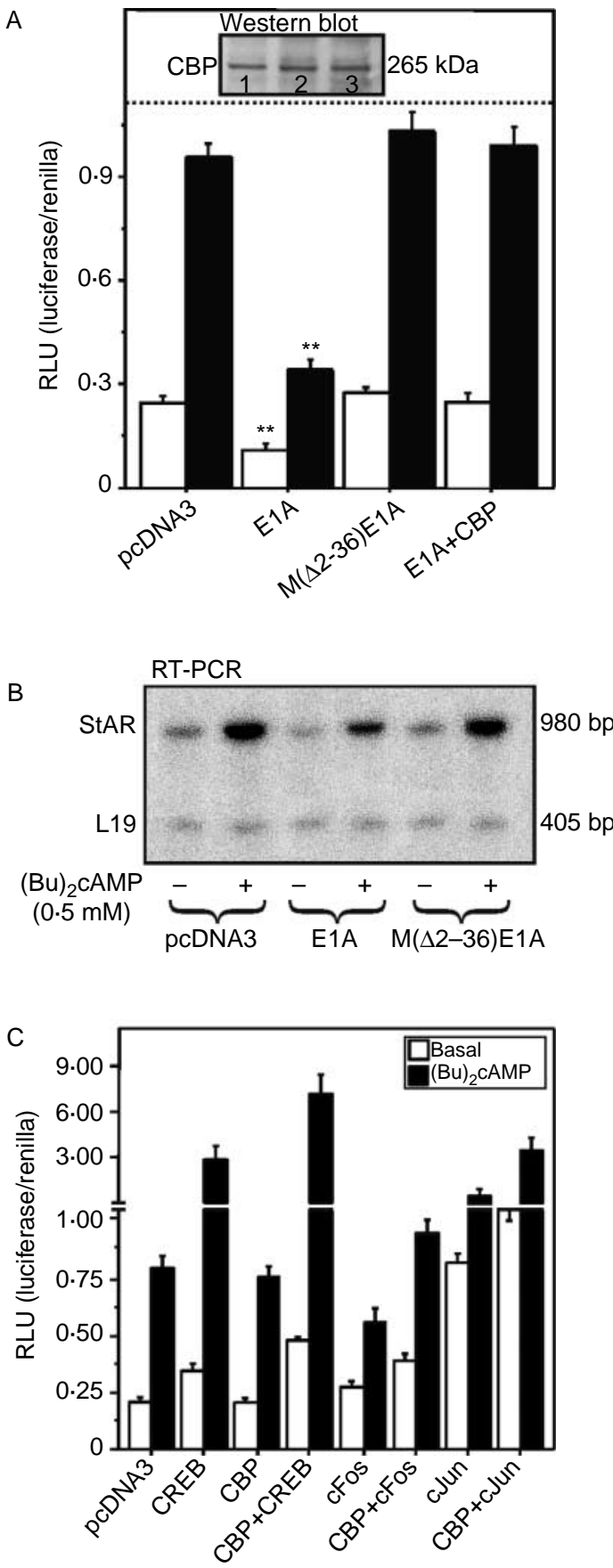

Journal of Molecular Endocrinology (2007) 39, 261-277

\section{Discussion}

Mechanisms regulating transcription include the roles of enhancer elements that function in 'switching on' and negative elements which 'silence' gene expression. Several closely related proteins constituting a family of transcription factors bind to some of these target regulatory elements (Montminy et al. 1986, Meyer \& Habener 1993, Sassone-Corsi 1995). The bZIP family of transcription factors is structurally similar in their DNAbinding domains but shows distinct binding specificity and function (Busch \& Sassone-Corsi 1990, Hai \& Curran 1991). DNA-binding motifs of the CRE/ATF and the AP-1/TRE family proteins are closely linked, bind each other, and are involved in regulating the transcription of several genes (Hoeffler et al. 1989, Masquilier \& Sassone-Corsi 1992). The presence of an overlapping, conserved CRE2/AP-1-binding site (TGACTGA), for CRE (CREB) and AP-1 (Fos/Jun) DNA-binding proteins, confers the potential for multiple effects on a single ciselement in regulating transcription of the StAR gene.

Cyclic AMP is an important intracellular second messenger for a number of extracellular stimuli and mediates the activation of transcription. The combined action of multiple DNA elements consisting of recognition motifs for sequence-specific transcription factors has been demonstrated in the cAMP-mediated regulation of StAR gene transcription (Reinhart et al. 1999, Wooton-Kee \& Clark 2000, Manna et al. 2003a, 2004). The data presented here demonstrate that both CRE and AP-1 DNA-binding proteins interact with the CRE2/AP-1 sequence. Specifically, this motif binds CREB, cFos, and

Figure 10 Involvement of CBP in StAR gene expression. (A) MA10 cells were transfected with either empty vector (pcDNA3) or expression plasmids containing $\mathrm{E} 1 \mathrm{~A}, \mathrm{M}(\Delta 2-36) \mathrm{E} 1 \mathrm{~A}$, and $\mathrm{E} 1 \mathrm{~A}$ plus CBP in the presence of the $-151 /-1$ StAR promoter reporter. Following $36 \mathrm{~h}$ of transfection, cells were incubated for a further $6 \mathrm{~h}$ in the absence (open bars) or presence of $0.5 \mathrm{mM}$ $(\mathrm{Bu})_{2} \mathrm{CAMP}$ (closed bars), and luciferase activity in the cell lysates was determined and expressed as RLU (luciferase/renilla). CBP protein levels were determined in mock (lane 1), E1A (lane 2), and $\mathrm{M}(\Delta 2-36) \mathrm{E} 1 \mathrm{~A}$ (lane 3 ) expressing $\mathrm{MA}-10$ cells by immunoblotting (using $22 \mu \mathrm{g}$ total protein) as shown by the data in the inset in (A), which is representative of three independent experiments. Cells were also transfected with pcDNA, $E 1 A$, and $M(\Delta 2-36) E 1 A$ expression plasmids. (B) Following $36 \mathrm{~h}$ of transfection, cells were treated for an additional $6 \mathrm{~h}$ without or with $(\mathrm{Bu})_{2} \mathrm{CAMP}$ and subjected to total RNA isolation for RT-PCR analysis of StAR mRNA expression. A representative autoradiogram $(n=3)$ illustrates expression of StAR mRNA in the different groups. (C) The effect of CBP in the activation of CREB and cFos/cJunmediated StAR promoter responsiveness. MA-10 cells were transfected with pcDNA, CREB, cFos, cJun, and CBP expression plasmids, or a combination of them, in the presence of the $-151 /-1$ StAR reporter. Following $36 \mathrm{~h}$ of transfection, cells were incubated for a further $6 \mathrm{~h}$ in the absence (Basal) or presence of $0.5 \mathrm{mM}(\mathrm{Bu})_{2} \mathrm{CAMP}$. Luciferase activity in the cell lysates was determined and expressed as RLU (luciferase/renilla). Data represent the mean \pm S.E.M. of three to four independent experiments. ${ }^{\star \star} P<0.01$ versus pcDNA. 
cJun proteins. Disruption of the CRE2/AP-1 site attenuated CREB and Fos/Jun-mediated StAR reporter activity under both basal and $(\mathrm{Bu})_{2}$ cAMP-stimulated conditions. The CRE1 and CRE3 elements recognized CREB protein, but not cFos and cJun, indicating that these CRE sites play roles in CREB responsiveness (Manna et al. 2002b, 2003b). These results strengthen previous studies demonstrating that CREB activation of a promoter includes the binding of multiple CRE-binding factors to several CREs rather than the binding of a single dimer (Liu et al. 1991, Roesler et al. 1995). On the other hand, varying effects of Fos and Jun on StAR gene transcription, essentially attenuating $(\mathrm{Bu})_{2} \mathrm{cAMP}-m e d i a t e d$ responsiveness, have been previously demonstrated (Shea-Eaton et al. 2002, Manna et al. 2004). Studies have also reported opposing actions of Fos and Jun on transcription of the phosphopyruvate carboxykinase, myogenic helix-loop-helix, and the gonadotropin-releasing hormone genes (Gurney et al. 1992, Li et al. 1992, Bruder et al. 1996).

The CRE2/AP-1 sequence in the StAR promoter is neither a canonical CRE nor a TRE; in fact, this motif is more closely related to an AP-1 consensus sequence than to a CRE consensus sequence. Our current data demonstrate that CREB and cFos/cJun displayed both positive and negative effects on StAR gene expression, observations in general agreement with previous findings (Gurney et al. 1992, Bruder et al. 1996, Manna et al. 2002b, 2004, Shea-Eaton et al. 2002). Also, CRE and AP-1 DNA-binding activity correlated with the phosphorylation of CREB, cFos, and cJun in MA-10 cells. Studies have shown that CREB phosphorylation at Ser133 is a prerequisite for its interaction with the CBP (Chrivia et al. 1993, Parker et al. 1996). In contrast, Fos and Jun phosphorylation result in both activation and inhibition of DNA binding and gene transcription, indicating a complex relationship between phosphorylation and function (Boyle et al. 1991, Baker et al. 1992, Abate et al. 1993).

An intriguing aspect of the present findings is that transcription factors belonging to the CRE (activated by cAMP) and AP-1 (activated by phorbol ester) signal transduction pathways affect each other's function. This appears to be due to the overlap of the CRE2/AP-1 sequences that bind both CREB and cFos/cJun dimers and result in transcriptional repression of the StAR gene. EMSA and reporter gene analyzes demonstrated that activation of StAR gene transcription by CREB was negatively modulated by cFos/cJun and that the CRE2/AP-1 site is indispensable for CREB and Fos/Jun-mediated trans-repression. Consistent with this, it has been reported that CRE DNA-binding proteins bind to the AP- 1 target sequence and repress transcriptional activation mediated by Fos/Jun (Masquilier \& Sassone-Corsi 1992, Rutberg et al. 1999).

In view of our present findings, it appears that CBP plays an integral role in the transcriptional regulation of the StAR gene. Activation of second messenger pathways triggers phosphorylation of sequence-specific DNA-binding transcription factors, which results in interaction of these factors with $\mathrm{CBP} / \mathrm{p} 300$ and modulation of their trans-activation potential (Parker et al. 1996, Fronsdal et al. 1998, Ray et al. 2002, Kovacs et al. 2003). Our findings demonstrate that $(\mathrm{Bu})_{2}$ cAMP increased P-CREB, P-cFos, and $\mathrm{P}-\mathrm{cJun}$ in a temporal manner, resulting in a high $\mathrm{P}$-CREB to $\mathrm{P}-\mathrm{cF}$ os/P-cJun ratio at extended times. In vivo ChIP studies demonstrated increased association of P-CREB, P-cFos/P-cJun, and CBP with the StAR proximal promoter, but not the distal, in response to $(\mathrm{Bu}){ }_{2} \mathrm{CAMP}$. In particular, the time course of the association between $\mathrm{P}-\mathrm{CREB}$ and $\mathrm{CBP}$ was concurrent, implicating the physical role of P-CREB-DNA interaction in CBP recruitment to the StAR promoter. Consequently, studies have demonstrated CREB/CREM, SF-1, GATA-4, C/EBP $\beta$, and cJun binding to the proximal StAR promoter as well as histone modifications that occurred in parallel to the association of CBP with the promoter following cAMP analog treatment (Hiroi et al. 2004, Clem et al. 2005). In fact, in addition to CREB and cFos/cJun, other factors that bind within the proximal $-151 /-1 \mathrm{bp}$ region and are involved in StAR transcription (and are phosphorylated by cAMP signaling, e.g., SF-1, GATA-4) may also enhance CBP recruitment to the StAR promoter. In a recent study, $\mathrm{CBP} / \mathrm{p} 300$ was shown to increase the ability of $\mathrm{C} / \mathrm{EBP} \beta$ and GATA-4 to trans-activate the StAR gene (Silverman et al. 2006). Therefore, it is plausible that the differences in transcription-binding patterns, especially the physical role of P-CREB-DNA and P-cFos/P-cJun-DNA interactions in CBP recruitment to the StAR promoter, and subsequent histone acetylation facilitates chromatin remodeling and thus increases StAR transcription.

$\mathrm{CBP} / \mathrm{p} 300$ is recognized as key molecules involved in the communication between transcription factors and basal transcriptional machinery, and thus play important roles in gene regulation (Vo \& Goodman 2001). In the present study, crosstalk between CREB and cFos/cJun at the overlapping CRE2/AP-1 motif was found to repress transcription of the StAR gene, an event tightly correlated with CBP recruitment to the StAR proximal promoter. Furthermore, CREB and cFos/cJun markedly decreased the association of CBP with the StAR promoter, which appeared to be due to competition of these factors for binding with the limiting amounts of intracellular CBP. This is likely to be a mechanism, at least in part, by which these factors suppress StAR gene expression. In support of this, it has been shown that the interference in transcriptional crosstalk between nuclear receptors and AP-1 for relatively low levels of the $\mathrm{CBP} / \mathrm{p} 300$ family of proteins occurs in different cells (Kamei et al. 1996, Fronsdal et al. 1998).

Previous evidence indicates that the DNA-binding factors which utilize $\mathrm{CBP} / \mathrm{p} 300$ as a coactivator may function either cooperatively or antagonistically 
depending upon the identity and conformation of complexes bound to the composite element (Kamei et al. 1996, Blobel et al. 1998, Vo \& Goodman 2001, Silverman et al. 2006). Transcriptional synergy requires the simultaneous interaction of multiple transcription factors with $\mathrm{CBP} / \mathrm{p} 300$ or comparable coactivators (Brindle et al. 1993, Vo \& Goodman 2001). Considering its role in modulating CREB and cFos/cJun-mediated StAR gene transcription in the face of activation of diverse signaling pathways, CBP appears to act as an integrator in the present study. The role of CBP in transactivation of the StAR gene was further elucidated when it was shown that the adenovirus E1A oncoprotein (but not mutant E1A) that binds the $\mathrm{C} / \mathrm{H} 3$ domain of $\mathrm{CBP} /$ p300, strongly attenuated StAR gene expression. Ectopic expression of CBP, which results in increases in $\mathrm{CBP}$, reversed trans-repression of the StAR gene by $\mathrm{E} 1 \mathrm{~A}$, an observation that agrees with our in vivo ChIP data demonstrating that endogenous levels of CBP were limiting. Loss of a single CBP allele, as seen in human Rubinstein-Taybi syndrome, results in severe developmental defects, illustrating that a small decrease in the concentrations of CBP can be deleterious (Petrij et al. 1995). Nonetheless, neither E1A nor mutant E1A altered the expression of CBP protein levels in MA-10 cells, suggesting repression of the StAR gene by E1A was not due to inhibition of CBP synthesis but rather to E1A interaction with CBP. E1A has been shown to be a potent inhibitor of $\mathrm{CBP} / \mathrm{p} 300 \mathrm{HAT}$ activity and binds to the same $\mathrm{C} / \mathrm{H} 3$ domain at which several key regulatory proteins interact (Chakravarti et al. 1999, Perissi et al. 1999, Ray et al. 2002). Thus, E1A appears to inhibit CBP

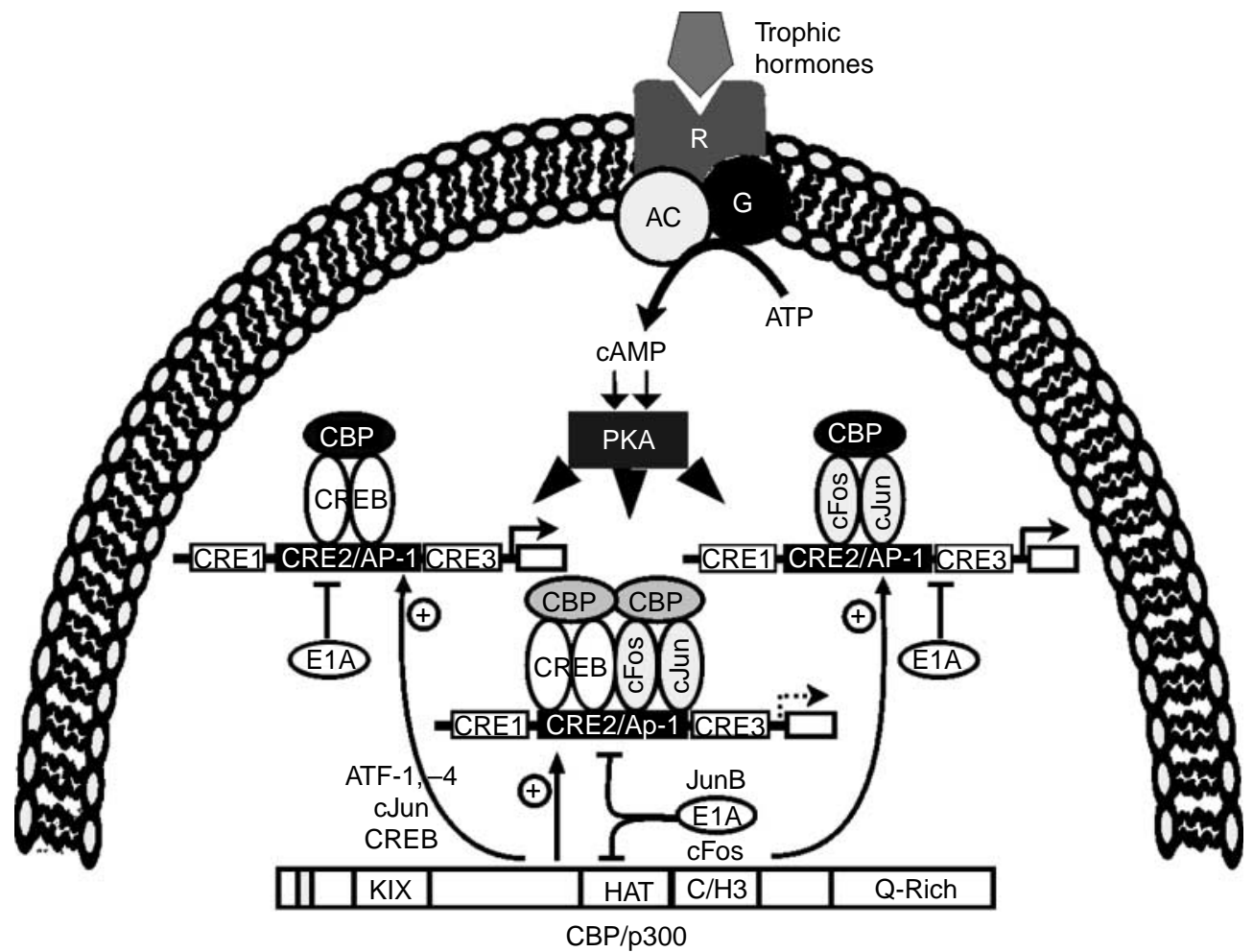

Figure 11 Proposed model of CRE2/AP-1-mediated StAR gene transcription. The interaction of trophic hormones with their specific receptors at the cell surface results in an activation of coupled $G$ protein $(G)$, which in turn stimulates membrane-associated adenylyl cyclase (AC). This, in turn, generates cAMP and results in the dissociation of the inactive PKA complex into the active catalytic and regulatory subunits. The catalytic subunits phosphorylate CREB and cFos/cJun, both of which bind to the CRE2/AP-1 motif in the StAR promoter and recruit the transcriptional coactivator CBP. Shown are models of CREB, cFos/cJun, or CREB and cFos/cJun interactions on a single cis-element in positive and negative regulation of StAR gene transcription. Binding of CREB to the CRE2/AP-1 element (as well as the CRE1 and CRE3 sites, not illustrated) in the StAR promoter alone activates both basal- and PKA-mediated transcription of the StAR gene (Manna et al. 2002b). On the other hand, cFos/cJun binding to the CRE2/AP-1 motif alone transactivates basal but decreases PKA-mediated StAR gene transcription (Manna et al. 2004). Simultaneous binding of CREB and cFos/cJun attenuates the association of CBP to the StAR promoter and results in suppression of StAR gene expression. CBP modulates the activity of CREB and cFos/cJun in StAR promoter responsiveness. $\mathrm{E} 1 \mathrm{~A}$ binds to the $\mathrm{C} / \mathrm{H} 3$ domain of $\mathrm{CBP} / \mathrm{p} 300$ and inhibits the adaptor function of $\mathrm{CBP} / \mathrm{p} 300$ leading to repression of $S t A R$ gene transcription. 
and subsequently repress $S t A R$ gene transcription by preventing the HAT activity of $\mathrm{CBP}$ and/or by inhibiting the interaction of CBP with other transcription factors or with the basal transcriptional machinery. Based on the results obtained, we propose a model illustrating three possible scenarios (contingent on the availability and specificity of CREB and cFos/cJun binding to the CRE2/AP-1 element in the StAR promoter and the involvement of these factors on CBP recruitment) that appear to be involved in the positive and negative regulation of StAR gene transcription (Fig. 11).

In summary, these findings provide insights into the mechanisms of intracellular signaling events and their association with the transcriptional regulation of the StAR gene. The competition for CBP binding by CREB and Fos/Jun and the resulting repression of the StAR gene suggest the involvement of similar regulatory events in diverse physiological responses that require stimulus-transcription coupling. The functional interaction/competition of the CRE and AP-1 DNA-binding proteins represent crosstalk between various signaling molecules that may be important in transcription of other steroidogenic genes that lack a consensus CRE but are regulated by cAMP-dependent mechanisms.

\section{Acknowledgements}

The authors would like to thank Dr Paolo Sassone-Corsi (Université Louis Pasteur, Strasbourg, France) and Dr Allan R Brasier (The University of Texas Medical Branch, Galveston, Texas) for the gifts of valuable reagents. This investigation was supported by NIH grant HD-17481 and with funds from the Robert A Welch Foundation grant B1-0028. The authors declare that there is no conflict of interest that would prejudice the impartiality of this scientific work.

\section{References}

Abate C, Luk D, Gagne E, Roeder RG \& Curran T 1990 Fos and jun cooperate in transcriptional regulation via heterologous activation domains. Molecular and Cellular Biology 10 5532-5535.

Abate C, Baker SJ, Lees-Miller SP, Anderson CW, Marshak DR \& Curran T 1993 Dimerization and DNA binding alter phosphorylation of Fos and Jun. PNAS 90 6766-6770.

Angel P, Imagawa M, Chiu R, Stein B, Imbra RJ, Rahmsdorf HJ, Jonat C, Herrlich P \& Karin M 1987 Phorbol ester-inducible genes contain a common cis element recognized by a TPA-modulated trans-acting factor. Cell 49 729-739.

Arany Z, Newsome D, Oldread E, Livingston DM \& Eckner R 1995 A family of transcriptional adaptor proteins targeted by the E1A oncoprotein. Nature 374 81-84.

Arias J, Alberts AS, Brindle P, Claret FX, Smeal T, Karin M, Feramisco J \& Montminy M 1994 Activation of cAMP and mitogen responsive genes relies on a common nuclear factor. Nature 370 226-229.
Ascoli M 1981 Characterization of several clonal lines of cultured Leydig tumor cells: gonadotropin receptors and steroidogenic responses. Endocrinology 108 88-95.

Baker SJ, Kerppola TK, Luk D, Vandenberg MT, Marshak DR, Curran T \& Abate C 1992 Jun is phosphorylated by several protein kinases at the same sites that are modified in serum-stimulated fibroblasts. Molecular and Cellular Biology 12 4694-4705.

Bannister AJ \& Kouzarides T 1995 CBP-induced stimulation of c-Fos activity is abrogated by E1A. EMBO Journal 14 4758-4762.

Bannister AJ, Oehler T, Wilhelm D, Angel P \& Kouzarides T 1995 Stimulation of c-Jun activity by CBP: c-Jun residues Ser63/73 are required for CBP induced stimulation in vivo and CBP binding in vitro. Oncogene 11 2509-2514.

Blobel GA, Nakajima T, Eckner R, Montminy M \& Orkin SH 1998 CREB-binding protein cooperates with transcription factor GATA-1 and is required for erythroid differentiation. PNAS 95 2061-2066.

Boyle WJ, Smeal T, Defize LH, Angel P, Woodgett JR, Karin M \& Hunter T 1991 Activation of protein kinase C decreases phosphorylation of c-Jun at sites that negatively regulate its DNA-binding activity. Cell 64 573-584.

Brindle P, Linke S \& Montminy M 1993 Protein kinase A-dependent activator in transcription factor CREB reveals new role for CREM repressors. Nature 364 821-824.

Bruder JM, Spaulding AJ \& Wierman ME 1996 Phorbol ester inhibition of rat gonadotropin-releasing hormone promoter activity: role of Fos and Jun in the repression of transcription. Molecular Endocrinology 10 35-44.

Busch SJ \& Sassone-Corsi P 1990 Dimers, leucine zippers and DNAbinding domains. Trends in Genetics 6 36-40.

Caron KM, Ikeda Y, Soo SC, Stocco DM, Parker KL \& Clark BJ $1997 a$ Characterization of the promoter region of the mouse gene encoding the steroidogenic acute regulatory protein. Molecular Endocrinology 11 138-147.

Caron KM, Soo SC, Wetsel WC, Stocco DM, Clark BJ \& Parker KL $1997 b$ Targeted disruption of the mouse gene encoding steroidogenic acute regulatory protein provides insights into congenital lipoid adrenal hyperplasia. PNAS $\mathbf{2 4} 827-834$.

De Cesare D \& Sassone-Corsi P 2000 Transcriptional regulation by cyclic AMP-responsive factors. Progress in Nucleic Acid Research and Molecular Biology 64 343-369.

Chakravarti D, Ogryzko V, Kao HY, Nash A, Chen H, Nakatani Y \& Evans RM 1999 A viral mechanism for inhibition of p300 and PCAF acetyltransferase activity. Cell 96 393-403.

Chen C \& Guo I-C 2000 Effect of cAMP on protein binding activities of three elements in upstream promoter of human CYP11A1 gene. Life Sciences 67 2045-2049.

Chrivia JC, Kwok RP, Lamb N, Hagiwara M, Montminy MR \& Goodman RH 1993 Phosphorylated CREB binds specifically to the nuclear protein CBP. Nature 365 855-859.

Clark BJ, Wells J, King SR \& Stocco DM 1994 The purification, cloning, and expression of a novel luteinizing hormone-induced mitochondrial protein in MA-10 mouse Leydig tumor cells. Characterization of the steroidogenic acute regulatory protein (StAR). Journal of Biological Chemistry 269 28314-28322.

Clem BF, Hudson EA \& Clark BJ 2005 Cyclic adenosine $3^{\prime}, 5^{\prime}$ monophosphate (cAMP) enhances cAMP-responsive element binding (CREB) protein phosphorylation and phospho-CREB interaction with the mouse steroidogenic acute regulatory protein gene promoter. Endocrinology 146 1348-1356.

Dignam JD, Lebovitz RM \& Roeder RG 1983 Accurate transcription initiation by RNA polymerase II in a soluble extract from isolated mammalian nuclei. Nucleic Acids Research 11 1475-1489.

Dwarki VJ, Montminy M \& Verma IM 1990 Both the basic region and the 'leucine zipper' domain of the cyclic AMP response element binding (CREB) protein are essential for transcriptional activation. EMBO Journal 9 225-232. 
Dynan WS \& Tjian R 1983 The promoter-specific transcription factor Sp1 binds to upstream sequences in the SV40 early promoter. Cell $\mathbf{3 5}$ 79-87.

Eckner R, Ewen ME, Newsome D, Gerdes M, DeCaprio JA, Lawrence JB \& Livingston DM 1994 Molecular cloning and functional analysis of the adenovirus E1A-associated $300-\mathrm{kD}$ protein (p300) reveals a protein with properties of a transcriptional adaptor. Genes and Development 8 869-884.

Fronsdal K, Engedal N, Slagsvold T \& Saatcioglu F 1998 CREB binding protein is a coactivator for the androgen receptor and mediates cross-talk with AP-1. Journal of Biological Chemistry 273 31853-31859.

de Groot RP, Delmas V \& Sassone-Corsi P 1994 DNA bending by transcription factors CREM and CREB. Oncogene 9 463-468.

Gurney AL, Park EA, Giralt M, Liu J \& Hanson RW 1992 Opposing actions of Fos and Jun on transcription of the phosphoenolpyruvate carboxykinase $(G T P)$ gene. Dominant negative regulation by Fos. Journal of Biological Chemistry 267 18133-18139.

Habener JF 1990 Cyclic AMP response element binding proteins: a cornucopia of transcription factors. Molecular Endocrinology 4 $1087-1094$.

Hai T \& Curran T 1991 Cross-family dimerization of transcription factors Fos/Jun and ATF/CREB alters DNA binding specificity. PNAS 88 3720-3724.

Hasegawa T, Zhao L, Caron KM, Majdic G, Suzuki T, Shizawa S, Sasano H \& Parker KL 2000 Developmental roles of the steroidogenic acute regulatory protein (StAR) as revealed by StAR knockout mice. Molecular Endocrinology 14 1462-1471.

Hiroi H, Christenson LK, Chang L, Sammel MD, Berger SL \& Strauss JF III 2004 Temporal and spatial changes in transcription factor binding and histone modifications at the steroidogenic acute regulatory protein (stAR) locus associated with stAR transcription. Molecular Endocrinology 18 791-806.

Hoeffler JP, Deutsch PJ, Lin J \& Habener JF 1989 Distinct adenosine $3^{\prime}, 5^{\prime}$-monophosphate and phorbol ester-responsive signal transduction pathways converge at the level of transcriptional activation by the interactions of DNA-binding proteins. Molecular Endocrinology 3 868-880.

Jo Y \& Stocco DM 2004 Regulation of steroidogenesis and steroidogenic acute regulatory protein in R2C cells by DAX-1 (dosage-sensitive sex reversal, adrenal hypoplasia congenita, critical region on the X chromosome, gene-1). Endocrinology 145 5629-5637.

Kamei Y, Xu L, Heinzel T, Torchia J, Kurokawa R, Gloss B, Lin SC, Heyman RA, Rose DW, Glass CK \& Rosenfeld MG 1996 A CBP integrator complex mediates transcriptional activation and AP-1 inhibition by nuclear receptors. Cell 85 403-414.

Kerppola TK \& Curran T 1991 Fos-Jun heterodimers and Jun homodimers bend DNA in opposite orientations: implications for transcription factor cooperativity. Cell 66 317-326.

Kovacs KA, Steinmann M, Magistretti PJ, Halfon O \& Cardinaux JR 2003 CCAAT/enhancer-binding protein family members recruit the coactivator CREB-binding protein and trigger its phosphorylation. Journal of Biological Chemistry 278 36959-36965.

Kwok RP, Lundblad JR, Chrivia JC, Richards JP, Bachinger HP, Brennan RG, Roberts SG, Green MR \& Goodman RH 1994 Nuclear protein CBP is a coactivator for the transcription factor CREB. Nature 370 223-226.

Laemmli UK 1970 Cleavage of structural proteins during the assembly of the head of bacteriophage T4. Nature 227 680-685.

Li L, Chambard JC, Karin M \& Olson EN 1992 Fos and Jun repress transcriptional activation by myogenin and MyoD: the amino terminus of Jun can mediate repression. Genes and Development 6 676-689.

Liu JS, Park EA, Gurney AL, Roesler WJ \& Hanson RW 1991 Cyclic AMP induction of phosphoenolpyruvate carboxykinase (GTP) gene transcription is mediated by multiple promoter elements. Journal of Biological Chemistry 266 19095-19102.
Manna PR \& Stocco DM 2005 Regulation of the steroidogenic acute regulatory protein expression: functional and physiological consequences. Current Drug Targets. Immune, Endocrine and Metabolic Disorders 5 93-108.

Manna PR, Tena-Sempere M \& Huhtaniemi IT 1999 Molecular mechanisms of thyroid hormone-stimulated steroidogenesis in mouse Leydig tumor cells. Involvement of the steroidogenic acute regulatory (StAR) protein. Journal of Biological Chemistry 274 5909-5918.

Manna PR, Huhtaniemi IT, Wang XJ, Eubank DW \& Stocco DM $2002 a$ Mechanisms of epidermal growth factor signaling: regulation of steroid biosynthesis and the steroidogenic acute regulatory protein in mouse leydig tumor cells. Biology of Reproduction 67 1393-1404.

Manna PR, Dyson MT, Eubank DW, Clark BJ, Lalli E, Sassone-Corsi P, Zeleznik AJ \& Stocco DM $2002 b$ Regulation of steroidogenesis and the steroidogenic acute regulatory protein by a member of the cAMP response-element binding protein family. Molecular Endocrinology 16 184-199.

Manna PR, Wang XJ \& Stocco DM $2003 a$ Involvement of multiple transcription factors in the regulation of steroidogenic acute regulatory protein gene expression. Steroids 68 1125-1134.

Manna PR, Eubank DW, Lalli E, Sassone-Corsi P \& Stocco DM $2003 b$ Transcriptional regulation of the mouse steroidogenic acute regulatory protein gene by the cAMP response-element binding protein and steroidogenic factor 1. Journal of Molecular Endocrinology 30 381-397.

Manna PR, Eubank DW \& Stocco DM 2004 Assessment of the role of activator protein-1 on transcription of the mouse steroidogenic acute regulatory protein gene. Molecular Endocrinology 18 558-573.

Manna PR, Chandrala SP, Jo Y \& Stocco DM 2006 a cAMP-independent signaling regulates steroidogenesis in mouse Leydig cells in the absence of StAR phosphorylation. Journal of Molecular Endocrinology 37 81-95.

Manna PR, Chandrala SP, King SR, Jo Y, Counis R, Huhtaniemi IT \& Stocco DM $2006 b$ Molecular mechanisms of insulin-like growth factor-I mediated regulation of the steroidogenic acute regulatory protein in mouse leydig cells. Molecular Endocrinology 20 362-378.

Masquilier D \& Sassone-Corsi P 1992 Transcriptional cross-talk: nuclear factors CREM and CREB bind to AP-1 sites and inhibit activation by Jun. Journal of Biological Chemistry 267 22460-22466.

Meyer TE \& Habener JF 1993 Cyclic adenosine $3^{\prime}, 5^{\prime}$-monophosphate response element binding protein (CREB) and related transcription-activating deoxyribonucleic acid- binding proteins. Endocrine Reviews 14 269-290.

Millhouse S, Kenny JJ, Quinn PG, Lee V \& Wigdahl B 1998 ATF/CREB elements in the herpes simplex virus type 1 latency-associated transcript promoter interact with members of the ATF/CREB and AP-1 transcription factor families. Journal of Biomedical Science $\mathbf{5}$ $451-464$.

Montminy M 1997 Transcriptional regulation by cyclic AMP. Annual Review of Biochemistry 66 807-822.

Montminy MR, Sevarino KA, Wagner JA, Mandel G \& Goodman RH 1986 Identification of a cyclic-AMP-responsive element within the rat somatostatin gene. PNAS 83 6682-6686.

Norwitz ER, Xu S, Xu J, Spiryda LB, Park JS, Jeong KH, McGee EA \& Kaiser UB 2002 Direct binding of AP-1 (Fos/Jun) proteins to a SMAD binding element facilitates both gonadotropin-releasing hormone (GnRH)- and activin-mediated transcriptional activation of the mouse GnRH receptor gene. Journal of Biological Chemistry 277 37469-37478.

O'Shea EK, Rutkowski R \& Kim PS 1992 Mechanism of specificity in the Fos-Jun oncoprotein heterodimer. Cell 68 699-708.

Parker D, Ferreri K, Nakajima T, LaMorte VJ, Evans R, Koerber SC, Hoeger C \& Montminy MR 1996 Phosphorylation of CREB at Ser133 induces complex formation with CREB-binding protein via a direct mechanism. Molecular and Cellular Biology 16 694-703. 
Perissi V, Dasen JS, Kurokawa R, Wang Z, Korzus E, Rose DW, Glass CK \& Rosenfeld MG 1999 Factor-specific modulation of CREB-binding protein acetyltransferase activity. PNAS 96 3652-3657.

Petrij F, Giles RH, Dauwerse HG, Saris JJ, Hennekam RC, Masuno M, Tommerup N, van Ommen GJ, Goodman RH, Peters DJ et al. 1995 Rubinstein-Taybi syndrome caused by mutations in the transcriptional co-activator CBP. Nature 376 348-351.

Rauscher FJ, III, Voulalas PJ, Franza BR, Jr. \& Curran T 1988 Fos and Jun bind cooperatively to the AP-1 site: reconstitution in vitro. Genes and Development 2 1687-1699.

Ray S, Sherman CT, Lu M \& Brasier AR 2002 Angiotensinogen gene expression is dependent on signal transducer and activator of transcription 3-mediated p300/cAMP response element binding protein-binding protein coactivator recruitment and histone acetyltransferase activity. Molecular Endocrinology 16 824-836.

Reinhart AJ, Williams SC, Clark BJ \& Stocco DM 1999 SF-1 (steroidogenic factor-1) and C/EBP beta (CCAAT/enhancer binding protein- $\beta$ ) cooperate to regulate the murine StAR (steroidogenic acute regulatory) promoter. Molecular Endocrinology 13 729-741.

Richards JS 2001 New signaling pathways for hormones and cyclic adenosine $3^{\prime}, 5^{\prime}$-monophosphate action in endocrine cells. Molecular Endocrinology 15 209-218.

Roesler WJ, Graham JG, Kolen R, Klemm DJ \& McFie PJ 1995 The cAMP response element binding protein synergizes with other transcription factors to mediate cAMP responsiveness. Journal of Biological Chemistry 270 8225-8232.

Rutberg SE, Adams TL, Olive M, Alexander N, Vinson C \& Yuspa SH 1999 CRE DNA binding proteins bind to the AP-1 target sequence and suppress AP-1 transcriptional activity in mouse keratinocytes. Oncogene 18 1569-1579.

Sassone-Corsi P 1995 Transcription factors responsive to cAMP. Annual Review of Cell and Development Biology 11 355-377.

Sassone-Corsi P, Ransone LJ \& Verma IM 1990 Cross-talk in signal transduction: TPA-inducible factor jun/AP-1 activates cAMPresponsive enhancer elements. Oncogene 5 427-431.

Shaywitz AJ \& Greenberg ME 1999 CREB: a stimulus-induced transcription factor activated by a diverse array of extracellular signals. Annual Review of Biochemistry 68 821-861.
Shea-Eaton W, Sandhoff TW, Lopez D, Hales DB \& McLean MP 2002 Transcriptional repression of the rat steroidogenic acute regulatory (StAR) protein gene by the AP-1 family member c-Fos. Molecular and Cellular Endocrinology 188 161-170.

Silverman E, Yivgi-Ohana N, Sher N, Bell M, Eimerl S \& Orly J 2006 Transcriptional activation of the steroidogenic acute regulatory protein $(S t A R)$ gene: GATA-4 and CCAAT/enhancer-binding protein beta confer synergistic responsiveness in hormone-treated rat granulosa and HEK293 cell models. Molecular and Cellular Endocrinology 252 92-101.

Stein RW, Corrigan M, Yaciuk P, Whelan J \& Moran E 1990 Analysis of E1A-mediated growth regulation functions: binding of the $300-\mathrm{kDa}$ cellular product correlates with E1A enhancer repression function and DNA synthesis-inducing activity. Journal of Virology 64 4421-4427.

Stocco DM \& Clark BJ 1996 Regulation of the acute production of steroids in steroidogenic cells. Endocrine Reviews 17 221-244.

Tan Y, Low KG, Boccia C, Grossman J \& Comb MJ 1994 Fibroblast growth factor and cyclic AMP (cAMP) synergistically activate gene expression at a cAMP response element. Molecular and Cellular Biology 14 7546-7556.

Vo N \& Goodman RH 2001 CREB-binding protein and p300 in transcriptional regulation. Journal of Biological Chemistry $\mathbf{2 7 6}$ $13505-13508$

Waterman MR 1995 A rising StAR: an essential role in cholesterol transport. Science 267 1780-1781.

Wooton-Kee CR \& Clark BJ 2000 Steroidogenic factor-1 influences protein-deoxyribonucleic acid interactions within the cyclic adenosine 3,5-monophosphate-responsive regions of the murine steroidogenic acute regulatory protein gene. Endocrinology 141 $1345-1355$.

Received in final form 17 July 2007

Accepted 3 August 2007

Made available online as an Accepted Preprint

9 August 2007 